\title{
Do migrants adopt new political attitudes from abroad? Evidence using a multi-sited exit-poll survey during the 2013 Malian elections
}

Lisa Chauvet ${ }^{1,2,3}$, Flore Gubert ${ }^{1,4}$ and Sandrine Mesplé-Somps ${ }^{1 *}$

* Correspondence: mesple@dial.prd.fr ${ }^{1}$ IRD, Université Paris-Dauphine, PSL Research University, LEDa, UMR [225], DIAL, 75016 Paris, France Full list of author information is available at the end of the article

\begin{abstract}
In this article, we examine whether migration experience provides an opportunity for Malian migrants to learn and adopt new political values and norms, and whether this translates into different attitudes towards domestic politics and institutions. We use a multi-sited exit-poll survey which was conducted during the Malian 2013 presidential election in Mali, France, and Côte d'Ivoire to investigate whether Malian migrants have different perceptions and political behavior than their non-migrant counterparts. By distinguishing between Malian migrants living in France and Côte d'Ivoire, we provide evidence that not only migrants have different perceptions of Malian democratic institutions than their non-migrant counterparts, but also that the institutional context of the host country matters for the adoption of political norms.
\end{abstract}

Keywords: Migration, Social remittances, Political norms, Africa

\section{Introduction}

With remittances being now recognized as one of the main sources of external funding for developing countries, most of the analyses investigating the relationship between migration and development have focused on the financial returns of migration for origin countries. However, the last 15 years have witnessed an increasing interest in "social remittances", that is the ideas, know-how, practices, and skills that are transferred by migrants from host to sending communities (Levitt, 1998, 2001). Closely tied to the paradigm of transnationalism, social remittances are considered by some authors as potentially having greater impacts on origin countries (see, e.g. Kapur \& McHale, 2005; Kapur, 2010). Yet, the existing empirical evidence to support this assertion is still limited, as the effects of the circulation of ideas, norms, and practices are hard to capture. One promising line of research in this field investigates the political changes induced by migration. Contact with more democratic countries may indeed change migrants' political beliefs and practices, and migrants may in turn transfer these newly-acquired political opinions to people in their origin countries when they return home or via cross-border connections. By so doing, migrants have the potential to be agents of change and help strengthen democracy in their home country (see, e.g. Batista \& Vicente, 2011).

(c) 2016 The Author(s). Open Access This article is distributed under the terms of the Creative Commons Attribution 4.0 International License (http://creativecommons.org/licenses/by/4.0/), which permits unrestricted use, distribution, and reproduction in any medium, provided you give appropriate credit to the original author(s) and the source, provide a link to the Creative Commons license, and indicate if changes were made. 
In this paper, we investigate whether migration experience provides an opportunity for Malian migrants to learn and adopt new political values and norms, and whether this translates into different attitudes towards domestic politics and institutions. Our assumption is that thanks to migration, individuals are confronted to a new environment and are naturally led to ask themselves how their home country compares to this new environment on various dimensions such as civil liberties, the functioning of institutions, etc. Depending on the institutional quality of the country they reside in, this comparison may be favorable or unfavorable to the home country and is likely to influence the perceptions migrants have on domestic political institutions. As a result, their perceptions should be different from the ones of non-migrants.

Our focus on Malian migrants is justified on two grounds: Mali's migration patterns on the one hand and Mali's experience with democracy on the other hand. With regards to the first point, Mali has a long-lasting history of migration both within the African continent and to Europe. According to household survey data collected in 2011, about 328,400 Malians reside abroad and 1.2 million Malian residents have undertaken at least one migration abroad over their lifetime out of a population of 15.9 million. ${ }^{1}$ As a result, $21 \%$ of the Malian population aged 15 or more live in a household with at least one member abroad and $48.4 \%$ in a household with at least one return migrant from abroad (Chauvet, Gubert, \& Mesplé-Somps, 2013; Sougane, 2015). Most international migrants reside in neighboring Western African countries, with Côte d'Ivoire being by far the main destination country. ${ }^{2}$ The colonial history of Mali, as well as its geographical situation has also resulted in significant migration flows from Mali to France since the end of the 1950s, and around $16 \%$ of Malian migrants currently reside in France (Chauvet et al., 2013). The size of the Malian diaspora, along with the close links that it keeps with its origin country, has made of migration an important phenomenon for the Malian society.

Turning to political issues, the situation of Mali has drastically evolved over the past years. Having had elected representatives at the national and local levels for 20 years, Mali was considered an example of smooth and successful transition to democracy. ${ }^{3}$ This vision lasted until March 22, 2012 when a coup d'état followed by an armed conflict with ethnic separatists and religious extremists in the Northern part of the territory endangered Mali's political system. ${ }^{4}$ Since then, the country has been considered as a fragile democracy. In terms of electoral participation, voter turnout has increased over the past 15 years from slightly less than $30 \%$ in the 1997 presidential election to around $50 \%$ in 2013. Participation rates remain low, though, which contrasts with the impressive number of political parties. In 2009, no less than one hundred parties participated to the local election. However, this high fragmentation hides the domination of the Alliance pour la Démocratie au Mali (ADEMA) over the Malian political life for more than a decade. With regards external voting, Mali has granted voting rights to its citizens living abroad since 1991. Considerably lower than the internal voter turnout, the external voter turnout was $19.3 \%$ in 2007 , but increased up to $44.6 \%$ in 2013 (Dedieu, 2013). This rise, which could have been even higher if the registration process had been simplified, illustrates the potentially important role played by Malian migrants in the political life of their origin country.

In order to assess whether migration experience translates into different attitudes towards domestic politics and institution, we draw on original data from the project 
"Political Impact of Migration" (POLECOMI). These data were collected through multi-sited election exit polls during the last Malian presidential elections, in July 2013, that is to say once democratic institutions have been restored after the coup of 2012 . The survey was designed so as to have three teams of surveyors in France, Côte d'Ivoire, and Mali, all of them interviewing Malian voters exiting polling places the day of the first round of the elections. Among destination countries, France was chosen for being a competitive multiparty democracy, by contrast to Côte d'Ivoire which is generally considered as a defective democracy. ${ }^{5}$ France and Côte d'Ivoire are also the main destination countries for Malian migrants, respectively in Europe and Africa. While the tradition of migration among the Malian population goes back to the precolonial period, the bulk of migration from Mali to Côte d'Ivoire and France occurred during the 1960s and 1970s due to the huge expansion of cocoa and coffee plantations in Côte d'Ivoire that need a lot of agricultural laborers, and to the demand of labor force of the manufacturing sector in France. At that period, migration flows to France were mainly composed of individuals coming from the region of Kayes, located in the Western part of the country, and belonging to the Soninke ethnic group (Gubert, 2000) whereas migrants to Côte d'Ivoire were originated from the South part of Mali (Sikasso region). While migration to these both countries has evolved and now includes individuals from other regions and ethnic backgrounds, the Kayes area and the South part of Mali remain the main regions of origin of Malian migrants.

We find that Malian migrants display different political attitudes than their fellow non-migrant counterparts in Mali. More specifically, we find that their perceptions on Malian democracy and institutions differ from Malian non-migrants. Their interest for politics and their implication in political matters are also affected by their migration experience. Moreover, the extent to which Malian migrants trust (or distrust) the institutions of their home country and the interest they have for Malian political life are found to depend on the country they reside in.

The remainder of the article is structured as follows. In Section 2, we provide a brief overview of the literature on social remittances and discuss the existing evidence on the relationship between migration experience and migrants' political attitudes. In Section 3, we present the exit poll data collected in the framework of the POLECOMI project, and describe our empirical strategy. Section 4 presents the results and provides some suggestive evidence on the channels that could drive our results. Section 5 concludes.

\section{Literature review}

There is now an abundant literature exploring the many ways and means migration impacts on origin countries. The most widely explored dimension of migration is migrants' financial remittances. As the second largest source of external funding for developing countries, remittances have been recognized as supplementing the incomes of millions of poor families and significantly contributing to reduce poverty. However, remittances in cash or goods are not the only links between migrants and their families of origin. As underlined by Peggy Levitt in her 2001 book, The Transnational Villagers, migrants also facilitate the cross-border diffusion of ideas, identities, beliefs, knowledge, and behavior which are now commonly referred to as social remittances. The latter circulate in several ways: through phone calls, letters, or the internet; when migrants 
return to their homeland; or when conversely non-migrants come to visit their friends or parents in their country of residence.

Drawing upon Levitt's conceptual framework, several recent papers have investigated the issue of international migration as a channel for the diffusion of fertility norms (see, e.g., Lindstrom \& Saucedo, 2002; Fargues, 2007; Beine, Docquier \& Schiff, 2013; Beine \& Sekkat, 2013; Bertoli \& Marchetta, 2015). Other authors have examined the spillover effects of migration in terms of health knowledge (see, e.g., Lindstrom \& Munoz-Franco, 2006; Hildebrandt \& McKenzie, 2005; Holdaway, Levitt, Fang, \& Rajaram, 2015). With regards to political norms or ideas, the question of whether migration is one of the possible ways through which the diffusion of democracy might take place has for a long time been mostly debated in the transnational literature at the theoretical level and illustrated using specific migrants communities experiences (see, e.g., Levitt, 2001; Morawska, 2002; Camp, 2003; Lauth \& Pickel, 2009 cited by Rüland, Kessler, \& Rother, 2009; Dedieu, Chauvet, Gubert, Mesplé-Somps \& Smith, 2013). It is only recently that some quantitative analyses have been carried out.

Among economists, the diffusion of political norms has first been tested at the macroeconomic level (Li \& McHale, 2006; Spilimbergo, 2009; Docquier, Lodigiani, Rapoport, \& Schiff, 2011; Beine \& Sekkat, 2013; Lodigiani \& Salomone, 2012). Overall, these studies find that openness to emigration has a positive effect on home-country institutional development. However, they do not allow to properly identifying the mechanisms at work, and only mention the home countries' increased exposure to new political values and practices thanks to contacts with return migrants and relatives abroad as one possible channel. To some extent, the same holds true with micro studies using data on electoral outcomes (Mahmoud, Rapoport, Steinmayr, \& Trebesch, 2013; Pfutze, 2012; Chauvet \& Mercier, 2014; Batista, Seither \& Vicente, 2014): overall, they find that electoral outcomes vary depending on the intensity of migration or return migration at the locality level, without being fully certain if this result can be interpreted as evidence of a diffusion of political norms and ideas by the migrants. ${ }^{6}$ One exception is Batista and Vicente (2011) who use a voting experiment and an instrumental variable strategy to show that international migration promotes better institutions at home by raising the demand for political accountability. The authors also show that this impact depends on which destination country migrants reside in (Portugal or United States).

One of the common underlying assumptions on which rest all these papers is that migration has the potential to alter or to strengthen migrants' political attitudes towards a more democratic direction. Indeed, a prerequisite for migrants to act as agents of change by channeling novel political beliefs and practices from their host country to their country of origin is that they themselves have had their beliefs and attitudes altered by their migration experience in the first place. As argued by Levitt (1998), however, not all migrants necessary absorb all ideas in the same way, and the degree to which migrants' attitudes are altered depends upon their interaction with the host society.

Following her contribution, a few authors have investigated whether contact with more democratic contexts through migration translates into democratic political attitudes in other contexts. Using data on a random sample of 650 voting-age Mexican citizens, Pérez-Armendáriz and Crow (2010) estimate multi-level logistic and linear regressions of political participation and attitudes on a set of individual characteristics including a variable of migration experience. They find that having lived abroad, in 
the United States or in Canada, makes respondents more tolerant and more critical of the Mexican government' record on rights than their counterparts who have never lived abroad. But the rate of political participation of returnees is found to be indistinguishable from that of other Mexicans. In the framework of a research project entitled "Democratisation through migration?", Rother (2009) conducts the same kind of analysis on Filipino migrants. However, the investigation is pushed a little bit further than in Pérez-Amendáriz and Crow (2009) through a comparison of former Overseas Filipino Workers (OFWs), coming back from various countries selected for being either democratic or authoritarian, with OFWs awaiting for their departure. The results suggest significant variation in the esteem returnees have for democratic values, personal freedom, labor rights, etc., depending on the country they come from. Those who personally benefited from the provision of rights relating to their situation during their stay (as is the case for OFWs who were in Hong-Kong) are found to be in higher agreement with democratic values than those who did not. In a similar vein, Careja and Emmenegger (2012) use data collected in 2002 among more than 10,000 individuals residing in Central and Eastern European countries to explore whether migrants returning from Western countries display different political attitudes than their fellow non-migrant citizens. They find a differentiated relationship between migration and political attitudes: while migrants and non-migrants show the same attitudes toward domestic politics, the two groups are found to differ with respect to their political participation, their satisfaction with how democracy works, and their interest for EU and foreign policy matters, with migrants participating more, being more satisfied, and more interested in politics than non-migrants. Moreover, only migration to established democracies is found to have a visible effect.

In sum, the existing evidence suggests that migration experience may contribute to shape migrants' political attitudes, in a way that has been found to depend on several factors. A strong limitation of this literature, however, is that endogeneity issues, while generally acknowledged, are not always properly dealt with. Some less democratic destinations may attract individuals who care less for democracy. More generally speaking, individuals may move abroad, because of their preference for democracy in the first place. Not taking this possibility into account may result in an over-estimation of the role of migration in shaping political attitudes. Our aim in this paper is thus to explore the impact of migration experience on migrants' political attitudes using an instrumentation strategy that correct for endogeneity. We do so with data on an African diaspora that, to our knowledge, has attracted little attention so far.

\section{Data and empirical strategy}

For the purpose of this research, we collected an original dataset on Malian voters interviewed in Mali, France, and Côte d'Ivoire during the first round of the last presidential election on July 28, 2013. ${ }^{7}$ To this end, we put in place multi-sited exit polls in different places: three suburbs of Paris (France), namely Bagnolet, Montreuil and Evry ${ }^{8}$; three communes located in the Northern part of Abidjan (Côte d'Ivoire), namely Abobo, Adjamé and Attécoubé; three localities in the region of Kayes - Kayes, Kenieba and Kita; and the communes I, IV and VI of Bamako (Mali). ${ }^{9}$ The choice of France and Côte d'Ivoire was driven by the fact that both are the main destination countries of Malian migrants, respectively in Europe and Africa. The focus on the capital cities and 
their suburbs was justified by the density of Malian migrants and polling stations in these localities, which facilitated the fieldwork and allowed us to interview large numbers of migrants in only one day. In Mali, we targeted the capital city of Bamako, as well as some localities in the Kayes region because a majority of Malian migrants to France originates from these places. Moreover, we restricted the sample to cities and did not sample polling stations in rural areas to facilitate the supervision of the fieldwork.

The multi-sited exit polls were conceived so as to be perfectly comparable across countries. The survey includes a core questionnaire with the same questions asked to all respondents, independently of their country or place of residence, as well as specific additional modules for migrants and non-migrants. The core questionnaire includes modules on respondents' main characteristics, perception on Malian democracy and institutions, and interest for politics and political activities in Mali. Interviewees in France and Côte d'Ivoire had to answer additional modules on their perception on democracy and institutions in their host country, their political activities in the host country, and their connections with their homeland. Interviewees in Mali had to answer additional modules on their past migration experience (if ever), and their connections with members of their household living abroad.

The final sample used in our analyses is composed of 188 Malian voters in France, 225 in Côte d'Ivoire, and 658 in Mali (with 338 and 320 voters being respectively interviewed in Bamako and Kayes). Since our objective is to compare migrants to non-migrants, individuals with a past migration experience, i.e. returnees, in the sample of Malians interviewed either in Bamako or Kayes are excluded from our analyses. ${ }^{10}$

In order to assess the impact of migration experience on migrants' political attitudes, we estimate the following general model:

$$
\text { POLITICAL }_{i}=\alpha+\beta X_{i}+\delta M I G R A N T_{i}+\varepsilon_{i}
$$

where POLITICAL $L_{\mathrm{i}}$ is meant to capture various dimensions of individual $i$ 's political attitudes and perceptions of Malian institutions. $X_{\mathrm{i}}$, is a set of individual $i$ 's characteristics and MIGRANT $T_{\mathrm{i}}$, is our variable of interest which indicates whether individual $i$ is currently living in France or in Côte d'Ivoire.

We assess the impact of migration on various dimensions of political attitudes and perceptions by estimating the model using 11 alternative dependent variables. The respondents' perception of Malian institutions is captured by the question of whether they tend to trust certain institutions including democracy $\left(D E M O C_{\mathrm{i}}\right)$, politicians before the coup $\left(\right.$ POLITIC $\left._{\mathrm{i}}\right)$, politicians after the coup $\left(\right.$ POLITIC $\left._{\mathrm{i}}\right)$, justice $\left(J U S T I C E_{\mathrm{i}}\right)$, the police $\left(P O L I C E_{\mathrm{i}}\right)$, the media $\left(M E D I A_{\mathrm{i}}\right)$, and the army $\left(A R M Y_{\mathrm{i}}\right)$. Answers are coded on a 4-point scale ranging from "I fully trust" (coded 1) to "I do not trust at all" (coded 4). We dichotomize the variables, with 1 indicating "full trust" and 0 otherwise.

Interest in politics is captured by four different variables: the first one is a dummy variable equal to one if the respondent declares having a strong interest for Malian politics $\left(I N T E R E S T_{\mathrm{i}}\right)$; the second variable is a dummy variable equal to one if the respondent had a strong interest for Malian 2013 elections (INTEREST2013 $\mathrm{i}_{\mathrm{i}}$. Finally, the last two variables are dummy variables taking the value 1 if the respondent is close to a political party in Mali $\left(C L O S E P O L_{\mathrm{i}}\right)$ and if he is a member of a political party in Mali $\left(M E M B E R P O L_{\mathrm{i}}\right)$. 
Perceptions and interest in politics may be differently influenced by migration experience depending on the institutional context and media prevailing in the destination country. In order to capture these differences, we distinguish between migrants living in France MIGFRANCE $E_{\mathrm{i}}$, and migrants in Côte d'Ivoire, MIGIVOIRE $E_{\mathrm{i}}$. These two variables are dummy variables taking the value 1 if the respondent was surveyed in France and Côte d'Ivoire respectively ( 0 otherwise).

Last, the set of control variables, $X_{\mathrm{i}}$, includes the respondents' main characteristics that are likely to influence their perceptions and interest in politics. These variables are age, sex, ethnic group, education and region of birth. ${ }^{11}$ Controlling for these individual characteristics is important because they may not only explain differences in the political attitudes of the respondents, but also be correlated with their propensity to migrate and their destination choice: in this case, omitting them from the model would bias the estimated impact of migration on political attitudes. The propensity to migrate has indeed been shown to be strongly dependent on individual characteristics such as age or education. In the case of Mali, it is also determined by ethnicity and region of birth: as it has been said before, the Soninke originating from the Kayes region, in Western Mali, have a long-lasting tradition of migration to France while those coming from the Southern part of Mali (Sikasso region) are strongly over-represented in the migration flows to Côte d'Ivoire.

Controlling for age, education, ethnicity and region of birth may not be sufficient, though, to preclude any bias in the estimation of the coefficient of the migration variables. Malian migrants may indeed have some specific unobservable attributes, such as risk aversion, entrepreneurial mindset or, say, a preference for democracy, which may both affect their probability to leave Mali and their political attitudes. In that case, the estimated coefficients of MIGFRANCE $E_{\mathrm{i}}$ and MIGIVOIRE $E_{\mathrm{i}}$ would be plagued by endogeneity. We therefore implement an identification strategy in which MIGFRANCE $E_{\mathrm{i}}$ and MIGIVOIRE $E_{\mathrm{i}}$ are instrumented by macroeconomic variables from the destination country that are unlikely to be correlated with political attitudes and perceptions, but are strongly correlated with migration status. For the emigration decision to France, we use the annual percentage growth rate of France's nominal GDP per capita ${ }^{12}$ since this variable is likely to provide a good indicator of the demand for workers, be they nationals or foreigners, and thus act as a pull factor among Malian migrant candidates. Following Wahba (2015), we use the growth rate of France's nominal GDP per capita when the individual is 24 years old, which is the average age at the time of departure for our sample of migrants. For the emigration decision to Côte d'Ivoire and given that the survey took place in the capital city of Abidjan, we use the annual number of fatalities due to civil or social conflicts in Abidjan when the individual is 24 years old as a potential deterrent to migration to Côte d'Ivoire (see a description of the data in ACLED 2013. In both first-stage estimations, we also use a dummy variable indicating whether the respondent is the household head $\left(H E A D_{\mathrm{i}}\right)$ as an additional instrument for our migration variables. For comparison purposes, we finally use alternatively ordinary least square estimators (OLS) and two stage least squares models (2SLS). ${ }^{13}$

Our estimations are run on three different sub-samples. We first compare Malian migrants living in France to non-migrants in Mali (excluding returnees). We then compare Malian migrants living in Côte d'Ivoire to non-migrants in Mali (again excluding returnees). Finally, we compare migrants in France and in Côte d'Ivoire to non-migrants. 
This last specification on the whole sample (excluding returnees) allows us to compare the coefficients estimated for each migrant category directly and to see whether migrants in France and migrants in Côte d'Ivoire differ significantly in terms of their political attitudes. As in the previous specifications, both OLS and 2SLS are alternatively used. However, when both migration variables are included simultaneously, the instruments perform poorly which leads us to present the results using the OLS estimator only. ${ }^{14}$

Whatever their country of residence, migrants are found to share some specific characteristics that distinguish them from their non-migrant counterparts: they are indeed more males, older, and less educated on average (detailed statistics are provided in Appendix, Table A1). As an illustration, while $24 \%$ of the non-migrants have achieved tertiary education, this is only so for 17 and $7 \%$ of the migrants in France and Côte d'Ivoire respectively. The same holds true for secondary education. As a result, the share of individuals who never went to school is much higher among migrants than among non-migrants, and especially so for migrants in Côte d'Ivoire. ${ }^{15}$

Turning to our dependent variables, Table 1 suggests that apart from a few exceptions, migrants in Côte d'Ivoire are characterized by higher levels of trust in Malian institutions than their non-migrant counterparts, while the reverse holds true for migrants in France. This stands as an indication that migration experience affects the political attitudes of migrants in ways that vary depending on the institutional environment prevailing in the host country. It may also indicate that more skeptical individuals favor migrating to France rather than to Côte d'Ivoire. Less clear patterns emerge from the variables aimed at capturing interest in politics. Overall, migrants are found to be on average more interested in Malian politics than their non-migrant counterparts, but are no more likely to be close to a Malian political party and less likely to be members of a Malian political party, which may reflect the difficulties of being actively involved in long-distance politics. However, before drawing strong conclusions, it is worthwhile testing whether these findings hold when controlling for the respondents' socioeconomic characteristics.

\section{Results}

Estimation results are presented in Tables 2, 3, and 4. Table 2 (respectively Table 3 ) displays the results of the regressions of our eleven dependent variables on a dummy variable for whether the respondent is a migrant in France (resp. Côte d'Ivoire). In both cases, the comparison group is made of the sampled non-migrants after excluding returnees. Table 4 displays the results of the regressions of the same set of outcome variables on two dummy variables for whether the respondent is a migrant in France or a migrant in Côte d'Ivoire using non-migrants as the comparison group. In each table, Panel A displays the regression results obtained after OLS estimations. In Tables 2 and 3, Panel B displays the regression results obtained after two-stage least squares estimations. Columns (1) to (7) show the estimated impact of migration experience on the level of trust in Malian institutions, while columns (8) to (11) show the estimated impact of migration experience on interest in domestic politics. ${ }^{16}$

Overall, the results suggest that respondents interviewed in France are characterized by lower levels of trust in Malian institutions than their non-migrant counterparts: the coefficient of the migration variable is negative in six out of seven regressions (see columns (1) to (7)) and significantly different from zero in five out of seven regressions. 
Table 1 Descriptive statistics of the dependent variables

\begin{tabular}{|c|c|c|c|c|c|}
\hline & $\begin{array}{l}\text { Name of the } \\
\text { variables }\end{array}$ & $\begin{array}{l}\text { Non } \\
\text { migrants }\end{array}$ & $\begin{array}{l}\text { Migrants in } \\
\text { France }\end{array}$ & $\begin{array}{l}\text { Migrants in Côte } \\
\text { d'lvoire }\end{array}$ & All \\
\hline \multicolumn{6}{|l|}{ High level of trust in... (Yes $=1)$} \\
\hline \multirow[t]{2}{*}{ Malian democracy } & \multirow[t]{2}{*}{$D_{E M O C_{i}}$} & 0.21 & 0.24 & 0.43 & 0.26 \\
\hline & & $(0.41)$ & $(0.43)$ & $(0.50)$ & $(0.44)$ \\
\hline Malian politicians & \multirow[t]{2}{*}{ POLITIC $C_{i}$} & 0.13 & 0.12 & 0.28 & 0.16 \\
\hline (before coup) & & $(0.33)$ & $(0.33)$ & $(0.45)$ & (0.36) \\
\hline Malian politicians & \multirow[t]{2}{*}{ POLITIC2 } & 0.34 & 0.15 & 0.37 & 0.32 \\
\hline (after coup) & & $(0.48)$ & $(0.36)$ & $(0.48)$ & $(0.47)$ \\
\hline \multirow[t]{2}{*}{ Malian justice } & \multirow[t]{2}{*}{ JUSTICE $E_{i}$} & 0.17 & 0.10 & 0.31 & 0.19 \\
\hline & & $(0.38)$ & $(0.31)$ & $(0.46)$ & $(0.39)$ \\
\hline \multirow[t]{2}{*}{ Malian police } & \multirow[t]{2}{*}{ POLICE } & 0.27 & 0.16 & 0.34 & 0.27 \\
\hline & & $(0.45)$ & $(0.36)$ & $(0.47)$ & $(0.44)$ \\
\hline \multirow[t]{2}{*}{ Malian media } & \multirow[t]{2}{*}{$M E D I A_{i}$} & 0.31 & 0.22 & 0.28 & 0.29 \\
\hline & & $(0.46)$ & $(0.42)$ & $(0.45)$ & $(0.45)$ \\
\hline \multirow[t]{2}{*}{ Malian army } & \multirow[t]{2}{*}{$A R M Y_{i}$} & 0.43 & 0.26 & 0.33 & 0.38 \\
\hline & & $(0.50)$ & $(0.44)$ & $(0.47)$ & $(0.49)$ \\
\hline \multicolumn{6}{|l|}{ High interest in... (Yes $=1)$} \\
\hline \multirow[t]{2}{*}{ Malian politics } & \multirow[t]{2}{*}{ INTEREST $_{i}$} & 0.36 & 0.56 & 0.45 & 0.42 \\
\hline & & $(0.48)$ & $(0.50)$ & $(0.50)$ & $(0.49)$ \\
\hline \multirow[t]{2}{*}{ Malian 2013 elections } & \multirow[t]{2}{*}{ INTEREST2013i } & 0.72 & 0.80 & 0.56 & 0.70 \\
\hline & & $(0.45)$ & $(0.40)$ & $(0.50)$ & $(0.46)$ \\
\hline \multirow[t]{2}{*}{ Close to a Malian political party } & \multirow[t]{2}{*}{ CLOSEPOL $_{i}$} & 0.59 & 0.56 & 0.58 & 0.58 \\
\hline & & $(0.49)$ & $(0.50)$ & $(0.49)$ & $(0.49)$ \\
\hline \multirow[t]{2}{*}{ Member of a Malian political party } & \multirow[t]{2}{*}{$M{ }^{\prime} M B E R P O L_{i}$} & 0.33 & 0.27 & 0.21 & 0.30 \\
\hline & & $(0.47)$ & $(0.45)$ & $(0.41)$ & $(0.46)$ \\
\hline Number of observations & & 658 & 188 & 225 & 1070 \\
\hline
\end{tabular}

Standard deviations in parentheses

More importantly, most of these results hold after instrumenting MIGFRANCE $E_{i}$, and the size of the coefficients slightly increases (Panel B), except for trust in the police (col. (5)) and in the media (col. (6)). However, whatever the specification, migration experience is found to affect neither trust in Malian democracy (col. (1)) or in Malian politicians before the coup d'état (col. (2).

As regards interest in politics (columns (8) to (11)), migrants in France are found to be more interested in Malian politics in general and to have had more interest for the 2013 presidential elections than their non-migrant counterparts, but this result should be considered with caution since it does not hold when we account for the endogeneity of MIGFRANCE.

If we now turn to migrants in Côte d'Ivoire, we find contrasted results. Panel A of Table 3 shows indeed that when compared with their non-migrant counterparts, respondents interviewed in Côte d'Ivoire have higher levels of trust in Malian democracy and in various Malian institutions including justice and the police while at the same time having a lower level of trust in the army. However, once instrumented, migration 
Table 2 Migrants in France vs. Non-migrants

\begin{tabular}{|c|c|c|c|c|c|c|c|c|c|c|c|}
\hline & (1) & (2) & (3) & (4) & (5) & (6) & (7) & (8) & (9) & (10) & (11) \\
\hline & $\mathrm{DEMOC}_{i}$ & POLITIC & POLITIC2 & JUSTICE $E_{i}$ & POLICE & $M E D I A_{i}$ & $A R M Y_{i}$ & INTEREST $_{i}$ & INTEREST2013i & $\begin{array}{l}\text { CLOSE } \\
\mathrm{POL}_{i} \\
\end{array}$ & $\begin{array}{l}\text { MEMBER } \\
\mathrm{POL}_{i}\end{array}$ \\
\hline \multicolumn{12}{|l|}{ Panel A - OLS } \\
\hline \multirow[t]{2}{*}{ MIGFRANCE } & 0.053 & -0.031 & -0.191 & -0.069 & -0.098 & -0.106 & -0.148 & 0.195 & 0.139 & -0.003 & -0.056 \\
\hline & $(1.33)$ & $(-0.95)$ & $(-4.32)^{* * *}$ & $(-1.93)^{*}$ & $(-2.38)^{* *}$ & $(-2.44)^{* *}$ & $(-3.15)^{* * *}$ & $(4.24)^{* * *}$ & $(3.28)^{* * *}$ & $(-0.07)$ & $(-1.26)$ \\
\hline Pseudo R2 & 0.048 & 0.016 & 0.069 & 0.036 & 0.059 & 0.060 & 0.056 & 0.075 & 0.040 & 0.042 & 0.034 \\
\hline Number of obs. & 843 & 843 & 837 & 840 & 845 & 843 & 844 & 849 & 848 & 848 & 848 \\
\hline \multicolumn{12}{|c|}{ Panel B - Two-stage least squares } \\
\hline \multirow[t]{2}{*}{ MIGFRANCE $E_{i}^{a}$} & 0.023 & -0.113 & -0.202 & -0.171 & -0.100 & -0.147 & -0.368 & 0.003 & 0.014 & -0.161 & -0.181 \\
\hline & $(0.22)$ & $(-1.28)$ & $(-1.65)^{*}$ & $(-1.76)^{*}$ & $(-0.90)$ & $(-1.25)$ & $(-2.86)^{* * *}$ & $(0.02)$ & $(0.12)$ & $(-1.26)$ & $(-1.49)$ \\
\hline Underidentif. test & 0.000 & 0.000 & 0.000 & 0.000 & 0.000 & 0.000 & 0.000 & 0.000 & 0.000 & 0.000 & 0.000 \\
\hline Weak ident. Test ${ }^{a}$ & 62.163 & 62.693 & 59.240 & 62.325 & 62.462 & 61.918 & 62.410 & 63.731 & 63.244 & 63.443 & 62.878 \\
\hline Sargan (p-value) & 0.728 & 0.996 & 0.966 & 0.091 & 0.278 & 0.698 & 0.755 & 0.271 & 0.848 & 0.390 & 0.688 \\
\hline Number of obs. & 843 & 843 & 837 & 840 & 845 & 843 & 844 & 849 & 848 & 848 & 848 \\
\hline
\end{tabular}


Table 3 Migrants in Côte d'Ivoire vs. Non-migrants

\begin{tabular}{|c|c|c|c|c|c|c|c|c|c|c|c|}
\hline & (1) & (2) & (3) & (4) & (5) & (6) & (7) & (8) & (9) & (10) & (11) \\
\hline & $\mathrm{DEMOC}_{i}$ & POLITIC & POLITIC2 & JUSTICE $E_{i}$ & POLICE & $M E D I A_{i}$ & $A R M Y_{i}$ & INTEREST $_{i}$ & $\begin{array}{l}\text { INTEREST } \\
2013_{i}\end{array}$ & $\begin{array}{l}\text { CLOSE } \\
P^{\prime} L_{i}\end{array}$ & $\begin{array}{l}\text { MEMBER } \\
\text { POL }_{i}\end{array}$ \\
\hline \multicolumn{12}{|l|}{ Panel A - OLS } \\
\hline \multirow[t]{2}{*}{ MIGIVOIRE $E_{i}^{a}$} & 0.257 & 0.159 & 0.036 & 0.129 & 0.126 & 0.029 & -0.082 & 0.110 & -0.157 & 0.019 & -0.023 \\
\hline & $(6.02)^{* * *}$ & $(4.34)^{* * *}$ & $(0.79)$ & $(3.21)^{* * *}$ & $(2.78)^{* * *}$ & $(0.64)$ & $(-1.68)^{*}$ & $(2.41)^{* *}$ & $(-3.58)^{* * *}$ & $(0.42)$ & $(-0.55)$ \\
\hline Pseudo R2 & 0.081 & 0.053 & 0.032 & 0.047 & 0.039 & 0.039 & 0.050 & 0.051 & 0.078 & 0.042 & 0.060 \\
\hline Number of obs. & 902 & 901 & 915 & 889 & 889 & 889 & 893 & 933 & 927 & 934 & 930 \\
\hline \multicolumn{12}{|c|}{ Panel A - Two-stage least squares } \\
\hline \multirow[t]{2}{*}{ MIGIVOIRE $E_{i}^{a}$} & 0.234 & 0.141 & -0.098 & 0.091 & 0.220 & 0.095 & -0.311 & -0.248 & -0.250 & -0.040 & -0.110 \\
\hline & $(1.86)^{*}$ & $(1.32)$ & $(-0.72)$ & $(0.77)$ & $(1.61)$ & $(0.70)$ & $(-2.14)^{* *}$ & $(-1.77)^{*}$ & $(-2.00)^{* *}$ & $(-0.29)$ & $(-0.87)$ \\
\hline Underidentif. test & 0.000 & 0.000 & 0.000 & 0.000 & 0.000 & 0.000 & 0.000 & 0.000 & 0.000 & 0.000 & 0.000 \\
\hline Weak ident. Test ${ }^{\mathrm{a}}$ & 55.606 & 55.682 & 56.255 & 55.267 & 51.814 & 52.386 & 54.637 & 55.904 & 61.480 & 57.415 & 56.104 \\
\hline Sargan test ( $p$ value) & 0.487 & 0.396 & 0.704 & 0.148 & 0.231 & 0.899 & 0.282 & 0.505 & 0.367 & 0.773 & 0.216 \\
\hline Number of obs. & 902 & 901 & 915 & 889 & 889 & 889 & 893 & 933 & 927 & 934 & 930 \\
\hline
\end{tabular}

(1) The reference category is "Being a non-migrant"

${ }^{*} p<0.10,{ }^{* *} p<0.05,{ }^{* * *} p<0.01$

Student's $t$ in parentheses

Additional controls include sex, ethnic groups, regions of birth, age and education variables. The list of instruments includes a dummy variable for whether the individual is the household head and the number of fatalities due to civil or social conflicts in Abidjan for when the individual is 24 years old (source: ACLED 2013)

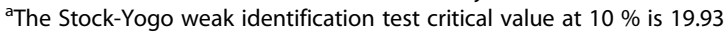


Table 4 Migrants in France and in Côte d'Ivoire vs. Non-migrants

\begin{tabular}{|c|c|c|c|c|c|c|c|c|c|c|c|}
\hline & (1) & (2) & (3) & (4) & (5) & (6) & (7) & (8) & (9) & (10) & (11) \\
\hline & $D E M O C_{i}$ & POLITIC & POLITIC2 $i$ & JUSTICE $E_{i}$ & POLICE & $M E D I A_{i}$ & $A R M Y_{i}$ & INTEREST $_{i}$ & $\begin{array}{l}\text { INTEREST } \\
2013_{i}\end{array}$ & $\begin{array}{l}\text { CLOSE } \\
\text { POL }_{i}\end{array}$ & $\begin{array}{l}\text { MEMBER } \\
\text { POL }_{i}\end{array}$ \\
\hline \multicolumn{12}{|l|}{ Panel A - OLS } \\
\hline \multirow[t]{2}{*}{ MIGFRANCE $E_{i}^{a}$} & 0.052 & -0.028 & -0.206 & -0.074 & -0.098 & -0.103 & -0.146 & 0.183 & 0.135 & 0.001 & -0.057 \\
\hline & $(1.27)$ & $(-0.82)$ & $(-4.69)^{* * *}$ & $(-2.01)^{* *}$ & $(-2.38)^{* *}$ & $(-2.43)^{* *}$ & $(-3.23)^{* * *}$ & $(4.09)^{* * *}$ & $(3.18)^{* * *}$ & $(0.02)$ & $(-1.37)$ \\
\hline \multirow[t]{2}{*}{ MIGIVOIRE $E_{\mathrm{i}}^{\mathrm{a}}$} & 0.247 & 0.147 & 0.029 & 0.123 & 0.123 & 0.031 & -0.096 & 0.124 & -0.168 & 0.035 & -0.039 \\
\hline & $(5.99)^{* * *}$ & $(4.24)^{* * *}$ & $(0.68)$ & $(3.29)^{* * *}$ & $(2.91)^{* * *}$ & $(0.71)$ & $(-2.08)^{* *}$ & $(2.83)^{* * *}$ & $(-4.03)^{* * *}$ & $(0.79)$ & $(-0.96)$ \\
\hline Pseudo R2 & 0.067 & 0.043 & 0.053 & 0.050 & 0.046 & 0.043 & 0.051 & 0.067 & 0.071 & 0.039 & 0.052 \\
\hline Number of obs. & 1,086 & 1,085 & 1,093 & 1,070 & 1,075 & 1,073 & 1,078 & 1,123 & 1,116 & 1,123 & 1,119 \\
\hline
\end{tabular}

aThe reference category is "Being a non migrant"

${ }^{*} p<0.10,{ }^{* *} p<0.05,{ }^{* * *} p<0.01$

Additional controls include sex, ethnic groups, regions of birth, age and education variables 
experience is no more significant, except in columns (1) and (7). This suggests that respondents in Côte d'Ivoire tend to be more satisfied with the way democracy works in their home country than their non-migrant counterparts (col. (1)), while at the same time distrusting more the army (col. (7)). This last finding is the only one that is common to migrants in France and migrants in Côte d'Ivoire. Most of the other results suggest that not every migration experience affects the political attitudes of migrants in significant ways. Last, columns (8) to (11) of Panel B suggest that migrants in Côte d'Ivoire are less interested and less involved in Malian politics than their non-migrant counterparts. Overall, our findings for migrants in France and Côte d'Ivoire are very much in line with those of other papers (see, among others, Batista \& Vicente, 2011; Careja \& Emmenegger, 2012). As for us, but using behavioral data collected in the migrant home country, namely Cape Verde, Batista and Vicente find that political attitudes are transferred by current and return migrants to residents in the home country with an intensity that depends on the countries of migrant destination. More precisely, they find that only emigrants to the US seem to have a sizable and significant impact on the desire for better governance. By contrast, the effects of emigrants to Portugal are not statistically significant.

Finally, the results relating to the control variables are displayed in Tables A2 and A3 in Appendix. Table A2 provides the 2SLS estimates obtained on the sample composed of migrants in France and non-migrants, while Table A3 provides the 2SLS estimates obtained on the sample composed of migrants in Côte d'Ivoire and non-migrants. Overall, the results suggest that male respondents are more interested in Malian politics and have higher levels of trust in Malian institutions than their female counterparts. But the coefficient is only significant in one out of 11 regressions in Table A2 and in two out of 11 regressions in Table A3. In both models, education is found to be positively correlated with individuals' interest in politics: educated individuals are indeed more likely to declare being close to or member of a Malian political party than individuals with no education. With regards to their perceptions of Malian institutions, by contrast, highly educated individuals do not significantly differ in terms of trust, except for the army that they distrust much more than their non-educated counterparts. No clear pattern emerges from the other control variables. Age and ethnicity in particular tend to have no effect on our outcome variables (with a few exceptions), whereas people coming from some regions (Kayes particularly) seem to have different degree of trust in the Malian institutions than the natives of Bamako (the reference category).

Finally, Table 4 displays the results of the regressions of the same set of outcome variables on two dummy variables for whether the respondent is a migrant in France or in Côte d'Ivoire using non-migrants as the comparison group. This last table is meant to go further in the understanding of the way the political and institutional context prevailing in the host country affects migrants' perceptions and interest in domestic politics. Because of a weak instrument problem, only OLS results are shown, which points to a need for caution in interpreting them. Overall, the results of Table 4 are in line with those of Tables 2 and 3. Migrants in France are found to be much more distrustful towards Malian institutions - especially regarding justice and police - than their Ivoirian and non-migrant counterparts and much more interested in Malian politics.

The above results suggest that migrant voters have different political attitudes and perceptions than their non-migrant counterparts, and that the differences depend on 
the country they reside in. This suggests in turn that the institutional characteristics of the country of destination matter.

As suggested by Levitt (1998), changes in individual political attitudes and perceptions also depend on the capacity and willingness of the migrants themselves to learn and adopt the values and norms of their host country. The degree to which their initial beliefs and ideas are altered is a function of their interaction with the host country's population which is likely to vary depending on their socio-economic characteristics and the cultural distance between them and the host society. ${ }^{17}$ Another channel through which migration might induce changes in political beliefs relates to the economic improvement it brings to migrants. Indeed, when individuals increase their personal economic resources in migration, they may be tempted to adopt the values and ideas of the country that they perceived as being the source of this expansion.

In order to see whether our data meet these assumptions, we compute simple descriptive statistics to see whether and to what extent migrants' appetite for democracy and skepticism towards their home country institutions vary according to some of their characteristics and the intensity of their interactions with the host society. As an indicator of socialization with the host country, we use migrants' host country media consumption as the latter is expected to trigger the adoption of new values and ideas. We also use a dummy variable for whether the migrant is a member of a trade union in the host country. Being a union member suggests indeed that the migrant has assimilated, that he is "politically incorporated" and that he has learnt the skills and commitments of democratic citizenship. Turning to the migrants' individual characteristics, we first use their level of education as a proxy for both their income level and their capacity and/or willingness to absorb news norms. Highly-educated migrants are expected to better integrate in their new environment as it is easier for them to find a job. Moreover, the kind of job they get is likely to make them more exposed to the cultural norms of their host country. Education is also likely to affect the composition of their network which may comprise relatively more educated non-migrant individuals than in the case of less-educated migrants. Finally, we characterize the place of residence of migrants to approximate to what extent they live in ethnic clusters or not. More precisely, for Malian migrants living in France - there is no equivalent in Côte d'Ivoire - we account for whether the individuals live in a 'foyer'. Almost one-fourth of our sample of migrants in France is concerned. 'Foyers' are residences in which migrants can rent a room (subsidized by the State) and share the facilities. This type of infrastructure is meant to help isolated migrants settle when they arrive in France. While it was meant as a temporary solution, the difficulty to find an alternative has sometimes led migrants to live in 'foyers' for many years. Most of the time, 'foyers' gather migrants from the same origin country. It provides an information on how isolated the migrants are - most of the time 'foyers' are meant for single men, without their family - but also on how apart from the host population the migrants live.

Tables 5 and 6 provide, for each of our 11 measures of political attitudes and perceptions, its average value according to whether migrants in France (Table 5) and Côte d'Ivoire (Table 6) get informed on French (respectively Ivoirian) political affairs by watching TV, reading newspapers, or listening to the radio; have tertiary education; are member of a union; and live in a foyer (for the French sample only). 
Table $\mathbf{5}$ Characteristics of migrants in France

\begin{tabular}{|c|c|c|c|c|c|c|c|c|c|}
\hline & \multirow[b]{2}{*}{ Non migrants } & \multicolumn{8}{|l|}{ Migrants in France } \\
\hline & & $\begin{array}{l}\text { With access to } \\
\text { media in France }\end{array}$ & $\begin{array}{l}\text { Without access to } \\
\text { media in France }\end{array}$ & $\begin{array}{l}\text { With tertiary } \\
\text { education }\end{array}$ & $\begin{array}{l}\text { Without tertiary } \\
\text { education }\end{array}$ & $\begin{array}{l}\text { Union } \\
\text { member }\end{array}$ & $\begin{array}{l}\text { Not a union } \\
\text { member }\end{array}$ & $\begin{array}{l}\text { Lives in } \\
\text { "foyer" }\end{array}$ & $\begin{array}{l}\text { Does not live in } \\
\text { "foyer" }\end{array}$ \\
\hline \multicolumn{10}{|l|}{ High level of trust in... } \\
\hline \multirow[t]{2}{*}{ Malian democracy } & 0.21 & 0.22 & 0.31 & 0.06 & 0.28 & 0.25 & 0.24 & 0.23 & 0.25 \\
\hline & $(0.41)$ & $(0.42)$ & $(0.47)$ & $(0.25)$ & $(0.45)$ & $(0.44)$ & $(0.43)$ & $(0.43)$ & $(0.43)$ \\
\hline Malian politicians & 0.13 & 0.10 & 0.19 & 0.03 & 0.14 & 0.14 & 0.11 & 0.21 & 0.10 \\
\hline (before the coup) & $(0.33)$ & $(0.30)$ & $(0.39)$ & $(0.18)$ & $(0.35)$ & $(0.35)$ & $(0.31)$ & $(0.41)$ & $(0.30)$ \\
\hline Malian politicians & 0.34 & 0.16 & 0.13 & 0.10 & 0.16 & 0.12 & 0.17 & 0.10 & 0.16 \\
\hline (after the coup) & $(0.48)$ & $(0.37)$ & $(0.34)$ & $(0.31)$ & $(0.37)$ & $(0.33)$ & $(0.38)$ & $(0.31)$ & $(0.37)$ \\
\hline \multirow[t]{2}{*}{ Malian Justice } & 0.17 & 0.05 & 0.24 & 0.00 & 0.12 & 0.09 & 0.11 & 0.15 & 0.09 \\
\hline & $(0.38)$ & $(0.22)$ & $(0.43)$ & $(0.00)$ & $(0.33)$ & $(0.29)$ & $(0.32)$ & $(0.37)$ & $(0.29)$ \\
\hline \multirow[t]{2}{*}{ Malian police } & 0.27 & 0.14 & 0.21 & 0.09 & 0.17 & 0.08 & 0.21 & 0.16 & 0.15 \\
\hline & $(0.45)$ & $(0.34)$ & $(0.41)$ & $(0.30)$ & $(0.37)$ & $(0.27)$ & $(0.41)$ & $(0.37)$ & $(0.36)$ \\
\hline \multirow[t]{2}{*}{ Malian media } & 0.31 & 0.20 & 0.28 & 0.06 & 0.25 & 0.16 & 0.27 & 0.26 & 0.21 \\
\hline & $(0.46)$ & $(0.40)$ & $(0.45)$ & $(0.25)$ & $(0.44)$ & $(0.37)$ & $(0.45)$ & $(0.45)$ & $(0.41)$ \\
\hline \multirow[t]{2}{*}{ Malian army } & 0.43 & 0.23 & 0.35 & 0.26 & 0.26 & 0.18 & 0.32 & 0.36 & 0.24 \\
\hline & $(0.50)$ & $(0.42)$ & $(0.48)$ & $(0.44)$ & $(0.44)$ & $(0.38)$ & $(0.47)$ & $(0.49)$ & $(0.43)$ \\
\hline \multicolumn{10}{|l|}{ High interest in... } \\
\hline \multirow[t]{2}{*}{ Malian politics } & 0.36 & 0.54 & 0.61 & 0.63 & 0.54 & 0.62 & 0.51 & 0.59 & 0.55 \\
\hline & $(0.48)$ & $(0.50)$ & $(0.49)$ & (0.49) & $(0.50)$ & $(0.49)$ & $(0.50)$ & $(0.50)$ & $(0.50)$ \\
\hline \multirow[t]{2}{*}{ Malian 2013 election } & 0.72 & 0.78 & 0.86 & 0.84 & 0.79 & 0.81 & 0.80 & 0.82 & 0.80 \\
\hline & $(0.45)$ & $(0.41)$ & $(0.35)$ & $(0.37)$ & $(0.41)$ & $(0.39)$ & $(0.40)$ & (0.39) & $(0.40)$ \\
\hline
\end{tabular}


Table 5 Characteristics of migrants in France (Continued)

\begin{tabular}{|c|c|c|c|c|c|c|c|c|c|}
\hline \multirow[t]{2}{*}{ Close to a political party } & 0.59 & 0.53 & 0.63 & 0.69 & 0.53 & 0.54 & 0.57 & 0.51 & 0.57 \\
\hline & $(0.49)$ & $(0.50)$ & $(0.49)$ & $(0.47)$ & $(0.50)$ & $(0.50)$ & $(0.50)$ & $(0.51)$ & $(0.50)$ \\
\hline \multirow[t]{2}{*}{ Mb. of a political party } & 0.33 & 0.27 & 0.29 & 0.45 & 0.24 & 0.27 & 0.28 & 0.15 & 0.30 \\
\hline & $(0.47)$ & $(0.44)$ & $(0.46)$ & $(0.51)$ & $(0.43)$ & $(0.44)$ & $(0.45)$ & $(0.37)$ & $(0.46)$ \\
\hline Number of observations & 658 & 139 & 49 & 32 & 156 & 79 & 109 & 39 & 149 \\
\hline
\end{tabular}

Standard deviations in parentheses

aMigrants who watch TV and/or read newspapers and/or listen to the radio or other media to get informed about French political affairs

"Migrants who do not "consume" any medium 
Table 6 Characteristics of migrants in Côte d'Ivoire

\begin{tabular}{|c|c|c|c|c|c|c|c|}
\hline & \multirow[b]{2}{*}{ Non migrants } & \multicolumn{6}{|l|}{ Migrants in Côte d'Ivoire } \\
\hline & & $\begin{array}{l}\text { With access to media in } \\
\text { Côte d'lvoire }^{\mathrm{a}}\end{array}$ & $\begin{array}{l}\text { Without access to media } \\
\text { in Côte d'Ivoire }\end{array}$ & With tertiary education & Without tertiary education & Union member & Not a union member \\
\hline \multicolumn{8}{|l|}{ High level of trust in... } \\
\hline \multirow[t]{2}{*}{ Malian democracy } & 0.21 & 0.45 & 0.41 & 0.40 & 0.43 & 0.25 & 0.44 \\
\hline & $(0.41)$ & $(0.50)$ & $(0.49)$ & $(0.51)$ & $(0.50)$ & $(0.45)$ & $(0.50)$ \\
\hline Malian politicians & 0.13 & 0.29 & 0.27 & 0.00 & 0.30 & 0.08 & 0.29 \\
\hline (before the coup) & $(0.33)$ & $(0.46)$ & $(0.45)$ & $(0.00)$ & $(0.46)$ & $(0.29)$ & $(0.46)$ \\
\hline Malian politicians & 0.34 & 0.34 & 0.40 & 0.33 & 0.37 & 0.17 & 0.39 \\
\hline (after the coup) & $(0.48)$ & $(0.48)$ & $(0.49)$ & $(0.49)$ & $(0.49)$ & $(0.39)$ & $(0.49)$ \\
\hline \multirow[t]{2}{*}{ Malian Justice } & 0.17 & 0.34 & 0.28 & 0.07 & 0.33 & 0.09 & 0.32 \\
\hline & $(0.38)$ & $(0.47)$ & $(0.45)$ & $(0.26)$ & $(0.47)$ & $(0.30)$ & $(0.47)$ \\
\hline \multirow[t]{2}{*}{ Malian police } & 0.27 & 0.36 & 0.32 & 0.13 & 0.36 & 0.27 & 0.35 \\
\hline & $(0.45)$ & $(0.48)$ & $(0.47)$ & $(0.35)$ & $(0.48)$ & $(0.47)$ & $(0.48)$ \\
\hline \multirow[t]{2}{*}{ Malian media } & 0.31 & 0.29 & 0.28 & 0.13 & 0.29 & 0.09 & 0.30 \\
\hline & $(0.46)$ & $(0.46)$ & $(0.45)$ & $(0.35)$ & $(0.46)$ & $(0.30)$ & $(0.46)$ \\
\hline \multirow[t]{2}{*}{ Malian army } & 0.43 & 0.33 & 0.33 & 0.07 & 0.35 & 0.18 & 0.34 \\
\hline & $(0.50)$ & $(0.47)$ & $(0.47)$ & $(0.26)$ & $(0.48)$ & $(0.40)$ & $(0.47)$ \\
\hline \multicolumn{8}{|l|}{ High interest in... } \\
\hline \multirow[t]{2}{*}{ Malian politics } & 0.36 & 0.38 & 0.52 & 0.67 & 0.43 & 0.75 & 0.44 \\
\hline & $(0.48)$ & $(0.49)$ & $(0.50)$ & $(0.49)$ & $(0.50)$ & $(0.45)$ & $(0.50)$ \\
\hline \multirow[t]{2}{*}{ Malian 2013 election } & 0.72 & 0.53 & 0.58 & 0.93 & 0.53 & 0.75 & 0.55 \\
\hline & $(0.45)$ & $(0.50)$ & (0.50) & $(0.26)$ & $(0.50)$ & $(0.45)$ & (0.50) \\
\hline
\end{tabular}


Table 6 Characteristics of migrants in Côte d'Ivoire (Continued)

\begin{tabular}{|c|c|c|c|c|c|c|c|}
\hline \multirow[t]{2}{*}{ Close to a political party } & 0.59 & 0.53 & 0.63 & 0.93 & 0.56 & 0.75 & 0.57 \\
\hline & $(0.49)$ & $(0.50)$ & $(0.48)$ & $(0.26)$ & $(0.50)$ & $(0.45)$ & $(0.50)$ \\
\hline \multirow[t]{2}{*}{ Mb. of a political party } & 0.33 & 0.22 & 0.21 & 0.40 & 0.20 & 0.50 & 0.20 \\
\hline & $(0.47)$ & $(0.41)$ & $(0.41)$ & $(0.51)$ & $(0.40)$ & $(0.52)$ & $(0.40)$ \\
\hline Number of observations & 658 & 111 & 114 & 15 & 210 & 12 & 213 \\
\hline
\end{tabular}

Standard deviations in parentheses

aMigrants who watch TV and/or read newspapers and/or listen to the radio or other media to get informed about Ivoirian political affairs

"Migrants who do not "consume" any medium 
Interestingly enough, Table 5 first shows that $74 \%$ (139 out of 188) of the migrants interviewed in France "use" French media to get informed about politics in France. Being exposed to French media is correlated to a stronger interest in French political affairs together with a higher level of skepticism towards Malian institutions and politicians and a lower interest in Malian politics, as shown by the differences in the means of our variables of interest between the two sub-samples of migrants in France. The same comparison between highly-educated migrants and less or no educated ones shows a much higher skepticism towards Malian institutions in the former group than in the latter one. As an illustration, only $6 \%$ of the highly-educated migrants trust Malian democracy, as compared to $28 \%$ of the migrants with lower level of education. Being highly-educated is also found to be associated with having a higher interest in Malian politics, as well as a higher propensity to be close to, or a member of, a Malian political party. The third proxy that we use to capture migrants' level of interaction with their host society is whether they are involved in some kind of activism through membership to a union. Again, being a unionist is found to be associated with higher skepticism towards Malian institutions.

The last dimension that we examine relates to the living conditions of Malians in France. As expected, Malian migrants who do not live in a 'foyer' and are likely to have more contact with the host society tend to be more distrustful towards Malian institutions (especially justice and the army) and politicians than their counterparts living in 'foyer'.

In Table 6, we present similar descriptive statistics for Malian migrants living in Côte d'Ivoire. Contrary to what is observed with migrants in France, getting informed on Ivoirian political affairs via Ivoirian media does not make much of a difference in terms of trust or distrust towards Malian institutions. This probably relates to the low quality and low reliability of Ivoirian media especially since the start of the Ivoirian political crisis. As a result, Ivoirian media do not really contribute to enhance migrants' free will and critical sense. By contrast, being highly-educated is, as for the French sample, found to be key in illustrating how the assimilation of individuals to their new environment may transform into the adoption of new political references. While Malian migrants living in Côte d'Ivoire are found to be on average less skeptical towards Malian institutions than their non-migrants counterparts, Table 6 shows that this is not true for the highly-educated ones whose perception of Malian institutions is on average much more critical. Highly-educated Malian migrants living in Côte d'Ivoire are also more interested in politics and more likely to be close to and member of a political party. The same holds true for unionists.

Overall, the results of Tables 5 and 6 thus provide suggestive evidence that depending on their personal attributes and living conditions, migrants are more or less likely to actively adopt new norms while in migration. They underline that migration per se is not enough to change opinions and behaviors. The degree of interaction and assimilation in the host society is critical for this adoption of norms to occur.

\section{Conclusion}

In this article, we examine whether migration experience provides an opportunity for Malian migrants to learn and adopt new political values and norms, and whether this translates into different attitudes towards domestic politics and institutions. We use an 
original multi-sited exit-poll survey which was conducted during the Malian 2013 presidential election in Mali, France, and Côte d'Ivoire to investigate whether Malian migrants have different perceptions and political behavior than their non-migrant counterparts. By distinguishing between Malian migrants living in France and Côte d'Ivoire, we provide evidence that non only migrants have different perceptions of Malian democratic institutions than non-migrants, but also that the institutional context of the host country matters for the adoption of political norms.

However, it is necessary to specify that our findings may overestimate the impact of migration on political opinions and attitudes as our empirical study has been conducted on a sample of voting migrants. They are probably more interested in politics than those who did not go to vote. Finally, this paper does not exactly investigate how powerful a mechanism migration is in the transmission of political norms but it suggests that migration drives such a kind or social remittances by showing that migrants' political opinions are impacted by the institutional context of their host countries.

\section{Endnotes}

${ }^{1}$ Migration is defined as having lived outside Mali more than six months.

${ }^{2}$ Three-fourths of the Malians living abroad live in Africa. Around $40 \%$ of Malian migrants live in Côte d'Ivoire (Chauvet et al., 2013).

${ }^{3}$ At least by the international community.

${ }^{4}$ For more detail on this event, see Thurston (2013), Wing (2013) or Whitehouse (2012).

${ }^{5}$ France's Polity IV score was +9 in 2014 while that of Côte d'Ivoire was +4 the same year. Mali had a score of +7 until 2012 which has fallen to +4 since then. According to the Centre for Systematic Peace in charge of the Polity IV Project, the Polity scores can be converted into three regime categories : "autocracies" $(-10$ to -6$)$, "anocracies" $(-5$ to +5$)$ and "democracies" (+6 to +10). (cf. http://www.systemicpeace.org/polity/polity4.htm)

${ }^{6}$ Actually, other channels like an income effect induced by financial remittances may come into play and interfere with the transfer of political norms.

${ }^{7}$ This election happened more than one year after the coup d'état and six months after the establishment of a transitional government.

${ }^{8}$ The city of Bagnolet hosts the Malian consulate.

${ }^{9}$ All the surveys were designed and supervised by the authors of the paper. For each survey, about ten investigators were involved. The field work were conducted in France by the authors of the paper and Jean-Philippe Dedieu, in Côte d'Ivoire by Marion Mercier and Anda David and in Mali by Arouna Sougane.

${ }^{10}$ These figures correspond to the number of fully-completed questionnaires, out of a total of 1,333 interviews. 107 returnees were additionally excluded from our analyses. Comparing current and past migrants' political attitudes as is done in Batista and Vicente (2011) would have been of great interest here, but the number of returnees from France and Côte d'Ivoire in our final sample was much too small (respectively 7 and 51 ) to get any significant and reliable results. We thus decided to drop them.

${ }^{11}$ Age is a categorical variable which distinguishes between the following age groups: $18-25,25-35,35-45,45-60,60-75$, and 75 and more. We computed seven dummy 
variables relating to ethnic groups. The education variables were constructed using information on the highest class achieved. We distinguish between primary, secondary, and tertiary education. In other regressions not shown here, we also included five dummy variables respectively equal to one if the migrant belongs to the village headman's family, the village's founding family, the land chief's family, religious leader's family or a marabout's family, but their overall contribution was not significantly different from 0 , so we opted for a more parsimonious set of regressors.

${ }^{12}$ Source: World Bank (2015).

${ }^{13}$ Non linear probit and IV probit models gave very similar results that are available upon request.

${ }^{14}$ The first-step tests (under- and weak-identification) suggests indeed that our instruments are too weak"to be trustworthy when MIGFRANCE and MIGIVOIRE are introduced simultaneously.

${ }^{15}$ The statistics provided in Table A1 also reveal how selected our sample of voters is. As an illustration, two thirds of the sampled (non-migrant) voters are men even though women and men were equally represented among voters at the last presidential elections. This can be partly explained by higher refusal rates among female voters who were asked to participate to our survey than among male voters. In a similar vein, the share of highly educated individuals in our sample of non-migrants is found to be much higher than the one observed in the general population. Part of this discrepancy certainly results from the over-representation of highly-educated individuals among voters. But a bias in favor of the highly-educated may also be present in our sample.

${ }^{16}$ Results of the first-stage equations are displayed in columns (1) and (2) of Table A4 in the Appendix. Being a migrant in France is found to be positively correlated with favorable macro conditions in France at the time of migration. Similarly, being a migrant in Côte d'Ivoire is found to be negatively correlated with the level of insecurity prevailing in Abidjan at the time of migration. Both migration variables are alsonegatively correlated with being the household head. Tests on the validity of the instruments (Sargan test, under-identification test and weak identification test) are not rejected, which suggests that our instruments are satisfactory.

${ }^{17}$ Using field work data collected in the city of Boston among Dominican migrants, Levitt identifies three broad patterns of interaction, which result in differentiated degree of attitudes alteration and of social remittance evolution. At one extreme are recipient observers, defined as individuals who mostly interact with their country fellows and take in new ideas and practices only by observing the world around them, reading the papers, and watching television. Given the limited interactions of the migrants with the host society, their norms and practices are therefore mainly unaltered. At the other extreme are purposeful innovators, defined as individuals who actively seek out new ideas, attitudes, and experiences. The migrants combine their original norms and values with those acquired in their host countries, leading through a cross-pollination to hybrid social norms (Levitt, 1998). Instrumental adapters stand in-between, and are defined as individuals who pragmatically acquire new skills and readjust their reference frame to better adapt to their new environment. Their original beliefs and values are unaltered by their migration experience, but they acquire new norms that they " $[a d d]$ to their cultural repertoire" (Levitt, 1998: 932). 


\section{Appendix}

Table 7 Respondents' main socio-economic characteristics

\begin{tabular}{|c|c|c|c|c|}
\hline & Non migrants & Migrants in France & Migrants in Côte d'Ivoire & All \\
\hline \multirow[t]{2}{*}{ Male } & 0.66 & 0.84 & 0.87 & 0.71 \\
\hline & $(0.47)$ & $(0.37)$ & $(0.34)$ & $(0.45)$ \\
\hline \multicolumn{5}{|l|}{ Age category } \\
\hline \multirow[t]{2}{*}{ [18-25] } & 0.27 & 0.03 & 0.09 & 0.19 \\
\hline & $(0.44)$ & $(0.18)$ & $(0.29)$ & $(0.39)$ \\
\hline \multirow[t]{2}{*}{$25-35[$} & 0.36 & 0.21 & 0.32 & 0.33 \\
\hline & $(0.48)$ & $(0.41)$ & $(0.47)$ & $(0.47)$ \\
\hline \multirow[t]{2}{*}{$35-45[$} & 0.19 & 0.39 & 0.28 & 0.24 \\
\hline & $(0.39)$ & $(0.49)$ & $(0.45)$ & $(0.43)$ \\
\hline \multirow[t]{2}{*}{$45-60[$} & 0.12 & 0.28 & 0.23 & 0.17 \\
\hline & $(0.32)$ & $(0.45)$ & $(0.42)$ & $(0.37)$ \\
\hline \multirow[t]{2}{*}{$60-75[$} & 0.05 & 0.09 & 0.07 & 0.06 \\
\hline & $(0.22)$ & $(0.28)$ & $(0.26)$ & $(0.24)$ \\
\hline \multirow[t]{2}{*}{75 or more } & 0.01 & 0.01 & 0.00 & 0.01 \\
\hline & $(0.12)$ & $(0.07)$ & $(0.07)$ & $(0.10)$ \\
\hline \multicolumn{5}{|l|}{ Level of education } \\
\hline \multirow[t]{2}{*}{ None } & 0.19 & 0.33 & 0.56 & 0.29 \\
\hline & $(0.40)$ & $(0.47)$ & $(0.50)$ & $(0.46)$ \\
\hline \multirow[t]{2}{*}{ Primary } & 0.28 & 0.29 & 0.28 & 0.28 \\
\hline & $(0.45)$ & $(0.46)$ & $(0.45)$ & $(0.45)$ \\
\hline \multirow[t]{2}{*}{ Secondary } & 0.29 & 0.21 & 0.10 & 0.23 \\
\hline & $(0.45)$ & $(0.41)$ & $(0.30)$ & $(0.42)$ \\
\hline \multirow[t]{2}{*}{ Tertiary } & 0.24 & 0.17 & 0.07 & 0.19 \\
\hline & $(0.42)$ & $(0.38)$ & $(0.25)$ & $(0.39)$ \\
\hline \multicolumn{5}{|l|}{ Region of birth } \\
\hline \multirow[t]{2}{*}{ Bamako } & 0.31 & 0.27 & 0.10 & 0.26 \\
\hline & $(0.46)$ & $(0.44)$ & $(0.30)$ & $(0.44)$ \\
\hline \multirow[t]{2}{*}{ Kayes } & 0.41 & 0.54 & 0.08 & 0.36 \\
\hline & $(0.49)$ & $(0.50)$ & $(0.28)$ & $(0.48)$ \\
\hline \multirow[t]{2}{*}{ Koulikoro } & 0.08 & 0.05 & 0.20 & 0.10 \\
\hline & $(0.28)$ & $(0.23)$ & $(0.40)$ & $(0.30)$ \\
\hline \multirow[t]{2}{*}{ Sikasso } & 0.05 & 0.02 & 0.15 & 0.07 \\
\hline & $(0.22)$ & $(0.13)$ & $(0.36)$ & $(0.25)$ \\
\hline \multirow[t]{2}{*}{ Segou } & 0.07 & 0.05 & 0.11 & 0.07 \\
\hline & $(0.25)$ & $(0.23)$ & $(0.31)$ & $(0.26)$ \\
\hline \multirow[t]{2}{*}{ Mopti } & 0.04 & 0.01 & 0.23 & 0.08 \\
\hline & $(0.21)$ & $(0.07)$ & $(0.42)$ & $(0.27)$ \\
\hline \multirow[t]{2}{*}{ Gao/Mopti/Kidal } & 0.02 & 0.01 & 0.04 & 0.02 \\
\hline & $(0.13)$ & $(0.10)$ & $(0.20)$ & $(0.15)$ \\
\hline \multirow[t]{2}{*}{ Abroad } & 0.01 & 0.06 & 0.09 & 0.04 \\
\hline & $(0.12)$ & $(0.24)$ & $(0.29)$ & (0.19) \\
\hline
\end{tabular}


Table 7 Respondents' main socio-economic characteristics (Continued)

\begin{tabular}{lllll}
\hline Ethnicity (Mother's tongue) & & & & \\
Bambara & 0.54 & 0.37 & 0.33 & 0.46 \\
Malinke & $(0.50)$ & $(0.48)$ & $(0.47)$ & $(0.50)$ \\
& 0.18 & 0.03 & 0.13 & 0.14 \\
Peul & $(0.39)$ & $(0.16)$ & $(0.34)$ & $(0.35)$ \\
& 0.06 & 0.05 & 0.08 & 0.06 \\
Sonraï/Djerma & $(0.24)$ & $(0.21)$ & $(0.27)$ & $(0.25)$ \\
& 0.04 & 0.01 & 0.02 & 0.03 \\
Dogon & $(0.19)$ & $(0.10)$ & $(0.13)$ & $(0.17)$ \\
& 0.03 & 0.01 & 0.19 & 0.06 \\
Soninke & $(0.16)$ & $(0.07)$ & $(0.39)$ & $(0.23)$ \\
& 0.08 & 0.43 & 0.12 & 0.15 \\
Khassonke & $(0.27)$ & $(0.50)$ & $(0.33)$ & $(0.36)$ \\
& 0.01 & 0.04 & 0.02 & 0.02 \\
Other & $(0.11)$ & $(0.19)$ & $(0.13)$ & $(0.13)$ \\
& 0.06 & 0.07 & 0.12 & 0.08 \\
Number of observations & $(0.24)$ & $(0.25)$ & $(0.32)$ & $(0.26)$ \\
& 658 & 188 & 225 & 1070 \\
\hline
\end{tabular}

Standard deviations in parentheses 
Table 8 Migrants in France vs. Non-migrants. Two-stage least squares results

\begin{tabular}{|c|c|c|c|c|c|c|c|c|c|c|c|}
\hline & (1) & (2) & (3) & (4) & (5) & (6) & (7) & (8) & (9) & (10) & (11) \\
\hline & $D^{2} M O C_{i}$ & POLITIC & POLITIC2 ${ }_{i}$ & JUSTICE & POLICE & $M E D I A_{i}$ & $A R M Y_{i}$ & INTEREST & INTEREST2013i & CLOSEPOL $_{i}$ & MEMBER POL \\
\hline \multirow[t]{2}{*}{ MIGFRANCE } & 0.023 & -0.113 & -0.202 & -0.171 & -0.100 & -0.147 & -0.368 & 0.003 & 0.014 & -0.161 & -0.181 \\
\hline & $(0.22)$ & $(-1.28)$ & $(-1.65)^{*}$ & $(-1.76)^{*}$ & $(-0.90)$ & $(-1.25)$ & $(-2.86)^{* * *}$ & $(0.02)$ & $(0.12)$ & $(-1.26)$ & $(-1.49)$ \\
\hline \multirow[t]{2}{*}{ Male } & -0.020 & 0.005 & 0.059 & 0.007 & -0.029 & 0.010 & 0.047 & 0.107 & 0.022 & 0.065 & 0.047 \\
\hline & $(-0.60)$ & $(0.20)$ & (1.63) & $(0.23)$ & $(-0.86)$ & $(0.28)$ & $(1.20)$ & $(2.75)^{* * *}$ & $(0.61)$ & (1.63) & $(1.26)$ \\
\hline \multicolumn{12}{|c|}{ Ethnicity (Mother's tongue) [ref. is other] } \\
\hline \multirow[t]{2}{*}{ Bambara } & -0.018 & 0.031 & 0.090 & 0.042 & 0.141 & 0.072 & 0.100 & -0.022 & 0.022 & -0.032 & 0.034 \\
\hline & $(-0.31)$ & $(0.64)$ & $(1.37)$ & $(0.78)$ & $(2.28)^{* *}$ & $(1.11)$ & $(1.41)$ & $(-0.31)$ & $(0.35)$ & $(-0.45)$ & $(0.51)$ \\
\hline \multirow[t]{2}{*}{ Malinke } & 0.044 & 0.004 & 0.121 & 0.050 & 0.106 & 0.086 & 0.132 & 0.006 & 0.052 & 0.019 & 0.036 \\
\hline & $(0.62)$ & $(0.08)$ & (1.55) & $(0.78)$ & $(1.44)$ & $(1.11)$ & $(1.56)$ & $(0.07)$ & $(0.68)$ & $(0.22)$ & $(0.45)$ \\
\hline \multirow[t]{2}{*}{ Peul } & -0.004 & -0.007 & 0.014 & 0.129 & 0.061 & 0.040 & 0.097 & -0.118 & 0.088 & -0.013 & 0.020 \\
\hline & $(-0.05)$ & $(-0.10)$ & $(0.16)$ & $(1.79)^{*}$ & $(0.73)$ & $(0.45)$ & $(1.01)$ & $(-1.25)$ & $(1.02)$ & $(-0.14)$ & $(0.22)$ \\
\hline \multirow[t]{2}{*}{ Sonraï/Djerma } & 0.165 & -0.041 & 0.022 & 0.099 & 0.184 & 0.103 & 0.118 & -0.072 & 0.124 & 0.083 & 0.038 \\
\hline & $(1.52)$ & $(-0.47)$ & $(0.18)$ & $(1.01)$ & $(1.63)$ & $(0.87)$ & $(0.91)$ & $(-0.56)$ & $(1.05)$ & $(0.63)$ & $(0.30)$ \\
\hline \multirow[t]{2}{*}{ Dogon } & -0.044 & 0.001 & 0.008 & 0.056 & -0.079 & -0.038 & 0.208 & 0.039 & 0.003 & 0.103 & 0.055 \\
\hline & $(-0.37)$ & $(0.01)$ & $(0.06)$ & $(0.52)$ & $(-0.64)$ & $(-0.29)$ & $(1.47)$ & $(0.28)$ & $(0.03)$ & $(0.72)$ & $(0.41)$ \\
\hline \multirow[t]{2}{*}{ Soninke } & -0.036 & 0.073 & -0.022 & 0.074 & 0.071 & 0.097 & 0.133 & -0.092 & 0.002 & 0.010 & 0.082 \\
\hline & $(-0.47)$ & (1.18) & $(-0.25)$ & $(1.08)$ & $(0.90)$ & $(1.17)$ & $(1.46)$ & $(-1.02)$ & $(0.03)$ & $(0.11)$ & $(0.94)$ \\
\hline \multirow[t]{2}{*}{ Khassonke } & -0.126 & -0.028 & -0.096 & -0.010 & -0.106 & -0.077 & 0.080 & -0.220 & -0.076 & -0.135 & 0.015 \\
\hline & $(-1.04)$ & $(-0.28)$ & $(-0.71)$ & $(-0.09)$ & $(-0.84)$ & $(-0.58)$ & $(0.54)$ & $(-1.52)$ & $(-0.58)$ & $(-0.91)$ & $(0.10)$ \\
\hline \multicolumn{12}{|c|}{ Age category [ref. is 18-25] } \\
\hline \multirow[t]{2}{*}{$25-35[$} & -0.005 & 0.044 & 0.009 & -0.029 & -0.053 & -0.009 & -0.009 & 0.008 & 0.004 & -0.038 & 0.026 \\
\hline & $(-0.12)$ & $(1.31)$ & $(0.21)$ & $(-0.79)$ & $(-1.24)$ & $(-0.20)$ & $(-0.19)$ & $(0.17)$ & $(0.08)$ & $(-0.76)$ & $(0.55)$ \\
\hline
\end{tabular}


Table 8 Migrants in France vs. Non-migrants. Two-stage least squares results (Continued)

\begin{tabular}{|c|c|c|c|c|c|c|c|c|c|c|c|}
\hline \multirow[t]{2}{*}{ [35-45 [ } & -0.061 & 0.054 & 0.060 & 0.011 & -0.065 & 0.009 & -0.040 & 0.139 & -0.022 & -0.016 & 0.072 \\
\hline & $(-1.17)$ & $(1.27)$ & $(1.05)$ & $(0.24)$ & $(-1.20)$ & $(0.16)$ & $(-0.65)$ & $(2.27)^{* *}$ & $(-0.39)$ & $(-0.25)$ & $(1.22)$ \\
\hline \multirow[t]{2}{*}{ [45-60 [ } & 0.081 & 0.067 & -0.011 & -0.047 & -0.075 & -0.057 & -0.067 & 0.136 & 0.020 & 0.038 & 0.054 \\
\hline & (1.39) & $(1.40)$ & $(-0.18)$ & $(-0.91)$ & $(-1.25)$ & $(-0.90)$ & $(-0.97)$ & $(1.98)^{* *}$ & $(0.32)$ & $(0.54)$ & $(0.81)$ \\
\hline \multirow[t]{2}{*}{ [60-75 [ } & 0.012 & 0.063 & -0.021 & -0.083 & -0.072 & 0.059 & -0.019 & 0.021 & -0.119 & -0.190 & -0.007 \\
\hline & $(0.18)$ & $(1.09)$ & $(-0.27)$ & $(-1.31)$ & $(-0.99)$ & $(0.77)$ & $(-0.22)$ & $(0.25)$ & $(-1.57)$ & $(-2.24)^{* *}$ & $(-0.08)$ \\
\hline \multirow[t]{2}{*}{75 and more } & -0.233 & -0.111 & -0.209 & -0.210 & -0.059 & 0.077 & -0.060 & 0.022 & -0.021 & -0.182 & 0.265 \\
\hline & $(-1.49)$ & $(-0.86)$ & $(-1.21)$ & $(-1.39)$ & $(-0.36)$ & $(0.45)$ & $(-0.32)$ & $(0.12)$ & $(-0.12)$ & $(-0.96)$ & $(1.48)$ \\
\hline \multicolumn{12}{|c|}{ Level of education [ref. is No education] } \\
\hline \multirow[t]{2}{*}{ Primary } & 0.047 & -0.000 & -0.067 & 0.059 & -0.034 & 0.034 & -0.072 & 0.005 & -0.053 & 0.142 & 0.094 \\
\hline & $(1.16)$ & $(-0.01)$ & $(-1.47)$ & $(1.62)$ & $(-0.79)$ & $(0.77)$ & $(-1.47)$ & $(0.10)$ & $(-1.21)$ & $(2.87)^{* * *}$ & $(2.02)^{* *}$ \\
\hline \multirow[t]{2}{*}{ Secondary } & 0.022 & -0.018 & -0.006 & -0.035 & -0.054 & -0.011 & -0.108 & 0.046 & 0.036 & 0.123 & 0.174 \\
\hline & $(0.51)$ & $(-0.50)$ & $(-0.12)$ & $(-0.91)$ & $(-1.21)$ & $(-0.24)$ & $(-2.08)^{* *}$ & $(0.90)$ & $(0.76)$ & $(2.35)^{* *}$ & $(3.52)^{* * *}$ \\
\hline \multirow[t]{2}{*}{ Tertiary } & -0.030 & -0.031 & -0.069 & -0.015 & -0.017 & -0.059 & -0.108 & 0.129 & 0.065 & 0.122 & 0.166 \\
\hline & $(-0.66)$ & $(-0.82)$ & $(-1.34)$ & $(-0.37)$ & $(-0.35)$ & $(-1.17)$ & $(-1.96)^{*}$ & $(2.36)^{* *}$ & $(1.30)$ & $(2.18)^{* *}$ & $(3.15)^{* * *}$ \\
\hline \multicolumn{12}{|c|}{ Region of birth [ref. Bamako] } \\
\hline \multirow[t]{2}{*}{ Kayes } & -0.026 & -0.020 & 0.074 & 0.032 & 0.119 & 0.142 & 0.099 & 0.063 & 0.007 & 0.013 & 0.056 \\
\hline & $(-0.72)$ & $(-0.68)$ & $(1.83)^{*}$ & $(0.97)$ & $(3.16)^{* * *}$ & $(3.59)^{* * *}$ & $(2.29)^{* *}$ & $(1.46)$ & $(0.18)$ & $(0.30)$ & $(1.37)$ \\
\hline \multirow[t]{2}{*}{ Koulikoro } & -0.166 & -0.072 & 0.021 & -0.014 & -0.039 & -0.111 & 0.011 & -0.103 & 0.049 & -0.052 & -0.053 \\
\hline & $(-2.86)^{* * *}$ & $(-1.52)$ & $(0.33)$ & $(-0.27)$ & $(-0.65)$ & $(-1.76)^{*}$ & $(0.15)$ & $(-1.51)$ & $(0.79)$ & $(-0.75)$ & $(-0.80)$ \\
\hline \multirow[t]{2}{*}{ Sikasso } & -0.145 & -0.104 & -0.126 & -0.038 & -0.116 & -0.031 & -0.032 & -0.137 & 0.074 & -0.160 & -0.050 \\
\hline & $(-1.96)^{*}$ & $(-1.70)^{*}$ & $(-1.54)$ & $(-0.56)$ & $(-1.50)$ & $(-0.38)$ & $(-0.36)$ & $(-1.55)$ & $(0.91)$ & $(-1.78)^{*}$ & $(-0.59)$ \\
\hline \multirow[t]{2}{*}{ Segou } & -0.067 & -0.039 & 0.041 & 0.033 & 0.057 & 0.057 & 0.089 & -0.045 & -0.033 & -0.044 & -0.067 \\
\hline & $(-1.10)$ & $(-0.78)$ & $(0.61)$ & $(0.59)$ & $(0.90)$ & $(0.84)$ & $(1.22)$ & $(-0.62)$ & $(-0.50)$ & $(-0.60)$ & $(-0.95)$ \\
\hline
\end{tabular}


Table 8 Migrants in France vs. Non-migrants. Two-stage least squares results (Continued)

\begin{tabular}{|c|c|c|c|c|c|c|c|c|c|c|c|}
\hline \multirow[t]{2}{*}{ Mopti } & -0.058 & -0.047 & 0.114 & -0.057 & 0.017 & 0.034 & -0.142 & -0.181 & 0.015 & -0.054 & -0.043 \\
\hline & $(-0.66)$ & $(-0.64)$ & $(1.16)$ & $(-0.72)$ & $(0.18)$ & $(0.35)$ & $(-1.33)$ & $(-1.71)^{*}$ & $(0.15)$ & $(-0.50)$ & $(-0.42)$ \\
\hline Gao/Mopti/ & -0.389 & -0.105 & -0.097 & -0.102 & -0.027 & -0.100 & -0.071 & 0.043 & 0.044 & -0.198 & 0.010 \\
\hline Kidal & $(-3.01)^{* * *}$ & $(-0.99)$ & $(-0.68)$ & $(-0.88)$ & $(-0.20)$ & $(-0.71)$ & $(-0.46)$ & $(0.28)$ & $(0.32)$ & $(-1.26)$ & $(0.06)$ \\
\hline \multirow[t]{2}{*}{ Abroad } & 0.040 & 0.028 & 0.177 & 0.155 & 0.058 & 0.136 & 0.123 & 0.023 & 0.051 & 0.079 & -0.025 \\
\hline & $(0.41)$ & $(0.35)$ & $(1.65)^{*}$ & $(1.77)^{*}$ & $(0.58)$ & (1.28) & $(1.06)$ & $(0.20)$ & $(0.48)$ & $(0.68)$ & $(-0.22)$ \\
\hline \multirow[t]{2}{*}{ Constant } & 0.266 & 0.117 & 0.232 & 0.144 & 0.216 & 0.201 & 0.391 & 0.262 & 0.677 & 0.511 & 0.128 \\
\hline & $(3.55)^{* * *}$ & $(1.91)^{*}$ & $(2.80)^{* * *}$ & $(2.14)^{* *}$ & $(2.76)^{* * *}$ & $(2.45)^{* *}$ & $(4.36)^{* * *}$ & $(2.95)^{* * *}$ & $(8.35)^{* * *}$ & $(5.63)^{* * *}$ & (1.50) \\
\hline Underident. test & 0.000 & 0.000 & 0.000 & 0.000 & 0.000 & 0.000 & 0.000 & 0.000 & 0.000 & 0.000 & 0.000 \\
\hline Weak ident. Test ${ }^{(1)}$ & 62.163 & 62.693 & 59.240 & 62.325 & 62.462 & 61.918 & 62.410 & 63.731 & 63.244 & 63.443 & 62.878 \\
\hline Sargan (p value) & 0.728 & 0.996 & 0.966 & 0.091 & 0.278 & 0.698 & 0.755 & 0.271 & 0.848 & 0.390 & 0.688 \\
\hline Number of obs. & 843 & 843 & 837 & 840 & 845 & 843 & 844 & 849 & 848 & 848 & 848 \\
\hline
\end{tabular}

(1) The reference category is "Being a non-migrant"

${ }^{*} p<0.10 .{ }^{* *} p<0.05 .{ }^{* * *} p<0.01$

The list of instruments includes a dummy variable for whether the individual is the household head and real GDP par capita growth in France for when the individual is 24 yearsold (source: World Bank, 2015).

(1) The Stock-Yogo weak identification test critical value at $10 \%$ is 19.93

Student's $t$ in parentheses 
Table 9 Migrants in Côte d'Ivoire vs. Non-migrants. Two-stage least squares results

\begin{tabular}{|c|c|c|c|c|c|c|c|c|c|c|c|}
\hline & (1) & (2) & (3) & (4) & (5) & (6) & (7) & (8) & (9) & (10) & (11) \\
\hline & $D^{2} M O C_{i}$ & POLITIC & POLITIC2 & JUSTICE & POLICE & MEDIA & $A R M Y_{i}$ & INTEREST & INTEREST2013i & CLOSE POL & MEMBERPOL $_{i}$ \\
\hline \multirow[t]{2}{*}{$\overline{M I G I V O I R E_{\mathrm{i}}^{(1)}}$} & 0.234 & 0.141 & -0.098 & 0.091 & 0.220 & 0.095 & -0.311 & -0.248 & -0.250 & -0.040 & -0.110 \\
\hline & $(1.86)^{*}$ & $(1.32)$ & $(-0.72)$ & $(0.77)$ & $(1.61)$ & $(0.70)$ & $(-2.14)^{* *}$ & $(-1.77)^{*}$ & $(-2.00)^{* *}$ & $(-0.29)$ & $(-0.87)$ \\
\hline \multirow[t]{2}{*}{ Male } & 0.006 & 0.012 & 0.081 & 0.017 & -0.022 & 0.012 & 0.061 & 0.143 & 0.061 & 0.059 & 0.029 \\
\hline & $(0.17)$ & $(0.39)$ & $(2.04)^{* *}$ & $(0.49)$ & $(-0.57)$ & $(0.32)$ & (1.46) & $(3.51)^{* * *}$ & $(1.63)$ & $(1.45)$ & $(0.78)$ \\
\hline \multicolumn{12}{|c|}{ Ethnicity (Mother's tongue) [ref. is other] } \\
\hline \multirow[t]{2}{*}{ Bambara } & 0.034 & 0.043 & 0.055 & 0.047 & 0.116 & 0.069 & 0.085 & 0.011 & 0.056 & -0.008 & 0.015 \\
\hline & $(0.60)$ & $(0.88)$ & $(0.88)$ & $(0.88)$ & $(1.91)^{*}$ & $(1.13)$ & $(1.29)$ & $(0.18)$ & $(0.93)$ & $(-0.12)$ & $(0.26)$ \\
\hline \multirow[t]{2}{*}{ Malinke } & 0.085 & 0.040 & 0.091 & 0.025 & 0.056 & 0.051 & 0.115 & 0.017 & 0.071 & 0.070 & 0.021 \\
\hline & $(1.32)$ & $(0.73)$ & $(1.27)$ & $(0.42)$ & $(0.81)$ & $(0.73)$ & $(1.55)$ & $(0.23)$ & $(1.04)$ & $(0.98)$ & $(0.32)$ \\
\hline \multirow[t]{2}{*}{ Peul } & 0.075 & -0.010 & -0.043 & 0.135 & 0.039 & 0.081 & 0.134 & -0.099 & 0.051 & 0.059 & 0.029 \\
\hline & $(0.99)$ & $(-0.16)$ & $(-0.52)$ & $(1.89)^{*}$ & $(0.49)$ & $(0.99)$ & $(1.53)$ & $(-1.16)$ & $(0.65)$ & $(0.71)$ & $(0.38)$ \\
\hline \multirow[t]{2}{*}{ Sonraï/Djerma } & 0.209 & -0.008 & -0.039 & 0.078 & 0.183 & 0.098 & 0.076 & 0.017 & 0.109 & 0.082 & 0.027 \\
\hline & $(2.04)^{* *}$ & $(-0.09)$ & $(-0.34)$ & $(0.82)$ & $(1.69)^{*}$ & $(0.90)$ & $(0.65)$ & $(0.14)$ & $(1.00)$ & $(0.70)$ & $(0.25)$ \\
\hline \multirow[t]{2}{*}{ Dogon } & 0.189 & 0.061 & 0.041 & 0.103 & 0.009 & 0.022 & 0.193 & 0.123 & 0.098 & 0.032 & 0.061 \\
\hline & $(2.09)^{* *}$ & $(0.79)$ & $(0.41)$ & $(1.18)$ & $(0.10)$ & $(0.22)$ & $(1.83)^{*}$ & $(1.21)$ & $(1.04)$ & $(0.32)$ & $(0.67)$ \\
\hline \multirow[t]{2}{*}{ Soninke } & -0.026 & 0.013 & 0.010 & -0.018 & -0.029 & -0.005 & -0.013 & -0.045 & -0.108 & -0.043 & -0.010 \\
\hline & $-0.35)$ & $(0.20)$ & $(0.13)$ & $(-0.26)$ & $(-0.37)$ & $(-0.07)$ & $(-0.16)$ & $(-0.55)$ & $(-1.42)$ & $(-0.54)$ & $(-0.14)$ \\
\hline \multirow[t]{2}{*}{ Khassonke } & 0.102 & 0.085 & -0.078 & 0.075 & 0.025 & 0.167 & -0.003 & -0.133 & -0.117 & -0.066 & -0.096 \\
\hline & $(0.74)$ & $(0.73)$ & $(-0.52)$ & $(0.59)$ & $(0.17)$ & (1.14) & $(-0.02)$ & $(-0.85)$ & $(-0.81)$ & $(-0.43)$ & $(-0.68)$ \\
\hline \multicolumn{12}{|c|}{ Age category [ref. is 18-25] } \\
\hline \multirow[t]{2}{*}{ [25-35] } & -0.013 & 0.017 & 0.034 & -0.035 & -0.037 & -0.021 & -0.021 & -0.045 & -0.045 & -0.081 & 0.019 \\
\hline & $(-0.32)$ & $(0.51)$ & $(0.77)$ & $(-0.94)$ & $(-0.87)$ & $(-0.50)$ & $(-0.46)$ & $(-0.98)$ & $(-1.06)$ & $(-1.80)^{*}$ & $(0.47)$ \\
\hline
\end{tabular}


Table 9 Migrants in Côte d'Ivoire vs. Non-migrants. Two-stage least squares results (Continued)

\begin{tabular}{|c|c|c|c|c|c|c|c|c|c|c|c|}
\hline \multirow[t]{2}{*}{ [35-45] } & -0.012 & 0.072 & 0.074 & 0.008 & -0.050 & 0.041 & -0.034 & 0.088 & -0.026 & -0.094 & 0.054 \\
\hline & $(-0.25)$ & $(1.85)^{*}$ & (1.48) & $(0.19)$ & $(-1.05)$ & $(0.85)$ & $(-0.65)$ & $(1.70)^{*}$ & $(-0.53)$ & $(-1.85)^{*}$ & (1.17) \\
\hline \multirow[t]{2}{*}{ [45-60] } & -0.002 & -0.011 & 0.025 & -0.088 & -0.096 & -0.030 & -0.122 & 0.112 & -0.021 & 0.003 & 0.081 \\
\hline & $(-0.04)$ & $(-0.25)$ & $(0.44)$ & $(-1.79)^{*}$ & $(-1.75)^{*}$ & $(-0.55)$ & $(-2.05)^{* * *}$ & $(1.88)^{*}$ & $(-0.39)$ & $(0.06)$ & $(1.51)$ \\
\hline \multirow[t]{2}{*}{ [60-75] } & 0.025 & 0.008 & 0.042 & -0.100 & -0.101 & 0.023 & -0.149 & -0.044 & -0.128 & -0.181 & 0.007 \\
\hline & $(0.35)$ & $(0.13)$ & $(0.55)$ & $(-1.50)$ & $(-1.31)$ & $(0.29)$ & $(-1.84)^{*}$ & $(-0.56)$ & $(-1.73)^{*}$ & $(-2.34)^{* *}$ & $(0.10)$ \\
\hline \multirow[t]{2}{*}{75 and more } & -0.233 & -0.149 & -0.301 & -0.217 & -0.287 & 0.033 & -0.235 & 0.063 & -0.030 & -0.155 & -0.002 \\
\hline & $(-1.67)^{*}$ & $(-1.25)$ & $(-2.03)^{* *}$ & $(-1.67)^{*}$ & $(-1.96)^{*}$ & $(0.22)$ & $(-1.48)$ & $(0.41)$ & $(-0.21)$ & $(-1.02)$ & $(-0.02)$ \\
\hline \multicolumn{12}{|c|}{ Level of education [ref. is No education] } \\
\hline \multirow[t]{2}{*}{ Primary } & 0.081 & 0.020 & -0.082 & 0.041 & -0.026 & 0.062 & -0.055 & -0.067 & 0.010 & 0.113 & 0.133 \\
\hline & $(1.86)^{*}$ & $(0.53)$ & $(-1.70)^{*}$ & $(0.99)$ & $(-0.55)$ & $(1.31)$ & $(-1.09)$ & $(-1.32)$ & $(0.22)$ & $(2.27)^{* *}$ & $(2.94)^{* * *}$ \\
\hline \multirow[t]{2}{*}{ Secondary } & 0.022 & -0.014 & -0.026 & -0.047 & -0.022 & 0.045 & -0.119 & -0.093 & 0.066 & 0.112 & 0.207 \\
\hline & $(0.39)$ & $(-0.29)$ & $(-0.42)$ & $(-0.89)$ & $(-0.37)$ & $(0.75)$ & $(-1.83)^{*}$ & $(-1.40)$ & $(1.09)$ & $(1.73)^{*}$ & $(3.48)^{* * *}$ \\
\hline \multirow[t]{2}{*}{ Tertiary } & 0.015 & -0.037 & -0.092 & -0.042 & 0.001 & -0.009 & -0.191 & -0.004 & 0.105 & 0.097 & 0.151 \\
\hline & $(0.22)$ & $(-0.66)$ & $(-1.29)$ & $(-0.68)$ & $(0.02)$ & $(-0.12)$ & $(-2.50)^{* *}$ & $(-0.05)$ & $(1.54)$ & $(1.31)$ & $(2.22)^{* *}$ \\
\hline \multicolumn{12}{|c|}{ Region of birth [ref. Bamako] } \\
\hline \multirow[t]{2}{*}{ Kayes } & 0.023 & 0.024 & 0.062 & 0.036 & 0.167 & 0.169 & 0.131 & 0.023 & -0.013 & -0.003 & 0.060 \\
\hline & $(0.53)$ & $(0.66)$ & (1.33) & $(0.89)$ & $(3.67)^{* * *}$ & $(3.67)^{* * *}$ & $(2.65)^{* * *}$ & $(0.48)$ & $(-0.29)$ & $(-0.05)$ & (1.38) \\
\hline \multirow[t]{2}{*}{ Koulikoro } & -0.077 & -0.052 & -0.015 & 0.021 & -0.012 & -0.058 & 0.134 & 0.045 & 0.097 & 0.023 & -0.026 \\
\hline & $(-1.25)$ & $(-0.98)$ & $(-0.23)$ & $(0.37)$ & $(-0.19)$ & $(-0.88)$ & $(1.91)^{*}$ & $(0.65)$ & $(1.52)$ & $(0.34)$ & $(-0.41)$ \\
\hline \multirow[t]{2}{*}{ Sikasso } & 0.031 & 0.021 & 0.017 & 0.047 & -0.015 & 0.035 & 0.159 & 0.098 & 0.094 & -0.042 & -0.022 \\
\hline & $(0.44)$ & $(0.35)$ & $(0.21)$ & $(0.71)$ & $(-0.19)$ & $(0.46)$ & $(1.94)^{*}$ & $(1.22)$ & $(1.28)$ & $(-0.54)$ & $(-0.31)$ \\
\hline \multirow[t]{2}{*}{ Segou } & 0.052 & 0.005 & 0.086 & 0.024 & 0.046 & 0.051 & 0.147 & 0.015 & 0.033 & -0.025 & -0.062 \\
\hline & $(0.83)$ & $(0.09)$ & $(1.23)$ & $(0.41)$ & $(0.68)$ & $(0.75)$ & $(2.02)^{* *}$ & $(0.20)$ & $(0.50)$ & $(-0.36)$ & $(-0.96)$ \\
\hline
\end{tabular}


Table 9 Migrants in Côte d'Ivoire vs. Non-migrants. Two-stage least squares results (Continued)

\begin{tabular}{|c|c|c|c|c|c|c|c|c|c|c|c|}
\hline \multirow[t]{2}{*}{ Mopti } & -0.132 & -0.028 & 0.088 & -0.061 & -0.023 & -0.007 & 0.030 & 0.032 & 0.031 & -0.011 & -0.009 \\
\hline & $(-1.63)$ & $(-0.41)$ & $(0.99)$ & $(-0.80)$ & $(-0.27)$ & $(-0.08)$ & $(0.32)$ & $(0.35)$ & $(0.37)$ & $(-0.12)$ & $(-0.11)$ \\
\hline Gao/Mopti/ & -0.257 & -0.120 & -0.017 & -0.066 & -0.024 & 0.008 & 0.061 & 0.011 & 0.092 & -0.173 & -0.068 \\
\hline Kidal & $(-2.27)^{* *}$ & $(-1.24)$ & $(-0.14)$ & $(-0.61)$ & $(-0.20)$ & $(0.06)$ & $(0.47)$ & $(0.08)$ & $(0.77)$ & $(-1.36)$ & $(-0.58)$ \\
\hline \multirow[t]{2}{*}{ Abroad } & 0.022 & 0.015 & 0.157 & 0.149 & -0.019 & -0.029 & 0.199 & 0.219 & 0.076 & 0.111 & 0.009 \\
\hline & $(0.20)$ & $(0.17)$ & $(1.37)$ & $(1.47)$ & $(-0.17)$ & $(-0.25)$ & $(1.61)$ & $(1.85)^{*}$ & $(0.71)$ & $(0.96)$ & $(0.08)$ \\
\hline \multirow[t]{2}{*}{ Constant } & 0.134 & 0.074 & 0.259 & 0.148 & 0.182 & 0.137 & 0.393 & 0.340 & 0.620 & 0.521 & 0.135 \\
\hline & $(1.66)^{*}$ & $(1.07)$ & $(2.89)^{* * *}$ & $(1.96)^{* *}$ & $(2.13)^{* *}$ & (1.59) & $(4.24)^{* * *}$ & $(3.65)^{* * *}$ & $(7.17)^{* * *}$ & $(5.65)^{* * *}$ & $(1.61)$ \\
\hline Underident. test & 0.000 & 0.000 & 0.000 & 0.000 & 0.000 & 0.000 & 0.000 & 0.000 & 0.000 & 0.000 & 0.000 \\
\hline Weak ident. Test ${ }^{(1)}$ & 55.606 & 55.682 & 56.255 & 55.267 & 51.814 & 52.386 & 54.637 & 55.904 & 61.480 & 57.415 & 56.104 \\
\hline Sargan (p value) & 0.487 & 0.396 & 0.704 & 0.148 & 0.231 & 0.899 & 0.282 & 0.505 & 0.367 & 0.773 & 0.216 \\
\hline Number of obs. & 902 & 901 & 915 & 889 & 889 & 889 & 893 & 933 & 927 & 934 & 930 \\
\hline
\end{tabular}

(1) The reference category is "Being a non-migrant"

${ }^{*} p<0.10 .{ }^{* *} p<0.05$. ${ }^{* * *} p<0.01$

作 (source: ACLED 2013). Student's $t$ in parentheses. (1) The Stock-Yogo weak identification test critical value at $10 \%$ is 19.93 
Table 10 First stage regressions

\begin{tabular}{lll}
\hline & $(1)$ & $(2)$ \\
& MIGFRANCE $_{\mathrm{i}}$ (vs. Non-migrants) & MIGIVOIRE $\mathrm{i}_{\mathrm{i}}$ (vs. Non-migrants) \\
\hline Household head & $-0.3119^{* * *}$ & $-0.2755^{* * *}$ \\
& -11.15 & -10.43 \\
GDP growth in France & 0.0135 & \\
Nber of fatalities in Abidjan & 1.54 & $-.0002966^{* *}$ \\
& & -2.24 \\
Observations & & 930 \\
R-squared & 848 & 0.6365 \\
\hline$p<0.10 . * 0<0.05157$ & &
\end{tabular}

${ }^{*} p<0.10{ }^{* *} p<0.05 .{ }^{* * *} p<0.01$

Student's $t$ in parentheses

The list of control variables included in specifications (1) and (2) is gender, age, ethnicity, level of education and region

\section{Acknowledgements}

This research has been supported by the French National Research Agency. We thank Jean-Philippe Dedieu for his useful insights during the preparation of the surveys, and Marion Mercier, Anda David and Arouna Sougané for their help during the data collection. We also thank Devesh Kapur, Catia Batista, Cris Beauchemin, Jérome Valette and three anonymous referees for very helpful comments.

\section{Authors' contributions}

All authors read and approved the final manuscript.

\section{Competing interests}

The authors declare that they have no competing interests.

\section{Author details}

${ }^{1}$ IRD, Université Paris-Dauphine, PSL Research University, LEDa, UMR [225], DIAL, 75016 Paris, France. ${ }^{2}$ Banque de France, Paris, France. ${ }^{3}$ FERDI, Clermont-Ferrand, France. ${ }^{4}$ Paris School of Economics, Paris, France.

Received: 16 September 2015 Accepted: 13 May 2016

Published online: 03 November 2016

\section{References}

ACLED. (2013). Armed Conflict Location and Event Dataset'. Available at: http://www.acleddata.com/data/. Accessed March 2016.

Batista, C., Seither, J., \& Vicente, P. (2014). Migration, Institutions and Social Networks in Mozambique. (NOVAFRICA Working Paper). Lisbon: Nova University of Lisbon.

Batista, C., \& Vicente, P. (2011). Do migrants improve governance at home? Evidence from a voting experiment. The World Bank Economic Review, 25(1), pp. 77-104.

Beine, M., Docquier, F., \& Schiff, M. (2013). International migration, transfer of norms and home country fertility. Canadian Journal of Economics/Revue canadienne d'économique., 46(4), 1406-1430. Retrieved from http://perso. uclouvain.be/frederic.docquier/filePDF/BDS_FertilityNorms.pdf.

Beine, M., \& Sekkat, K. (2013). Skilled migration and the transfer of institutional norms. IZA Journal of Migration, 2(1), pp. 1-19.

Bertoli, S., \& Marchetta, F. (2015). Bringing It All back home-return migration and fertility choices. World Development, 65, pp. 27-40.

Camp, R. A. (2003). Learning democracy in Mexico and the United States. Mexican Studies, 19(1), pp. 3-27.

Careja, R., \& Emmenegger, P. (2012). Making democratic citizens the effects of migration experience on political attitudes in Central and Eastern Europe. Comparative Political Studies, 45(7), pp. 875-902.

Chauvet, L., Gubert, F., \& Mesplé-Somps, S. (2013). Transferts migratoires et Democratization [Migrant Remittances and Democratization]. In P. Gonin, N. Kotlok, \& M.-A. Pérouse de Montclos (Eds.), La Tragédie Malienne [The Malian tragedy]. Paris: Edition Vendémiaire.

Chauvet, L., \& Mercier, M. (2014). Do return migrants transfer political norms to their origin country? Evidence from Mali. Journal of Comparative Economics, 42, 630-651.

Dedieu, J-P. (2013). Mali's Scattered Democracy. How Migrants from Paris to Guangzhou Influence the Vote. Foreign Affairs. Retrieved from https://www.foreignaffairs.com/articles/mali/2013-08-12/malis-scattered-democracy.

Dedieu, J.-P., Chauvet, L., Gubert, F., Mesplé-Somps, S., \& Smith, E. (2013). The "battles" of Paris and New York. An analysis of the transnational electoral behaviour of Senegalese immigrants in France and the United States. Revue française de Sciences Politiques, 63(5), pp. 865-892.

Docquier, F., Lodigiani, E., Rapoport, H., \& Schiff, M. (2011). Emigration and democracy. (IZA Discussion Paper, no., 5496). Retrieved from http://ftp.iza.org/dp5496.pdf.

Fargues, P. (2007). The Demographic Benefit of International Migration: Hypothesis and Application to Middle Eastern and North African Contexts. In C. Ozden \& M. Schiff (Eds.), International Migration, Economic Development and Policy 
(pp. 161-182). Washington D.C: The World Bank. Retrieved from https://openknowledge.worldbank.org/bitstream/ handle/10986/6766/405230IntlOmig101 OFFICIALOUSEOONLY1.pdf? sequence=1\&isAllowed=y.

Gubert, F. (2000). Migration as a collective risk-coping strategy. Evidence from the Kayes area (Western Mali). (Doctoral dissertation). University of Auvergne.

Hildebrandt, N., \& McKenzie, D. J. (2005). The effects of migration on child health in Mexico. Economia, 6(1), 257-89. Retrieved from https://s3.amazonaws.com/ssrc-cdn1/crmuploads/new_publication_3/\%7BF394B238-ED51-DE11AFAC-001CC477EC70\%7D.pdf.

Holdaway, J., Levitt, P., Fang, J., \& Rajaram, N. (2015). Mobility and health sector development in China and India. Social Science \& Medicine, 130, pp. 268-276.

Kapur, D. (2010). Diaspora, Development, and Democracy: The Domestic Impact of International Migration from India. Princeton: Princeton University Press.

Kapur, D., \& McHale, J. (2005). Give Us Your Best and Brightest: The Global Hunt for Talent and Its Impact on the Developing World. Washington DC, WA: Center for Global Development.

Lauth, H. J., \& Pickel, G. (2009). Diffusion of Democracy transfer of a successful model. In G. Erdmann \& M. Kneuer (Eds.), Externe Faktoren der Demokratisierung [External factors of democratization] (pp. 37-74). Baden-Baden: Nomos. doi:10. 5771/9783845212067-37.

Levitt, P. (1998). Social remittances: migration driven local-level forms of cultural diffusion. International Migration Review, 32, pp. 926-948.

Levitt, P. (2001). The Transnational Villagers. Berkeley: University of California Press.

Li, X., \& McHale, J. (2006). Does brain drain lead to institutional gain? A cross country empirical investigation. Manuscript: Queen University. Retrieved from http://dse.univr.it/espe/documents/Papers/D/5/D5_3.pdf

Lindstrom, D. P., \& Munoz-Franco, E. (2006). Migration and maternal health services utilization in rural Guatemala. Social Science \& Medicine, 63(3), pp. 706-721.

Lindstrom, D. P., \& Saucedo, S. G. (2002). The short-and long-term effects of US migration experience on Mexican women's fertility. Social Forces, 80(4), 1341-1368.

Lodigiani, E., \& Salomone, S. (2012). Migration-Induced Transfers of Norms: The Case of Female Political Empowerment. (Centro Studi Luca d'Agliano Development Studies Working Paper, 343). Retrieved from http://www.creammigration.org/publ_uploads/CDP_20_13.pdf.

Mahmoud, O.T, Rapoport, H., Steinmayr, A., \& Trebesch, C. (2013). The effect of labor migration on the diffusion of democracy: evidence from a former Soviet Republic (CReAM Discussion Paper Series, CDP No 20/13). Retrieved from http://www.cream-migration.org/publ_uploads/CDP_20_13.pdf.

Morawska, E. (2001). International Migration and the Consolidation of Democracy. In A. Pravda \& J. Zielonka (Eds.), International and Transnational Factors. Democratic Consolidation in Eastern Europe 2 (pp. 163-191). Oxford: Oxford University Press. doi:10.1093/019924409X.003.0007.

Pérez-Armendáriz, C., \& Crow, D. (2010). Do Migrants Remit Democracy? International Migration, Political Beliefs, and Behavior in Mexico. Comparative Political Studies, 43(1), 119-148. first published online February 27, 2009 doi:10. $1177 / 0010414009331733$

Pfutze, T. (2012). Does migration promote democratization? Evidence from the Mexican transition". Journal of Comparative Economics, 40(2), pp. 159-175.

Rother, S. (2009). Changed in migration? Philippine return migrants and (un) democratic remittances. European journal of East Asian studies, 8(2), pp. 245-274.

Rüland, J., Kessler, C., \& Rother, S. (2009). Democratisation through international migration? Explorative thoughts on a novel research agenda. European Journal of East Asian Studies, 8(2), pp. 161-179.

Sougane, A. (2015). Migrations et transferts au Mali: un état des lieux [Migration and transfers in Mali: an overview]. In J. Charmes, D. Konaté, \& J. Brunet-Jailly (Eds.), Le Mali contemporain [The contemporary Mali] (pp. 613-642). Tombouctou: Editions IRD.

Spilimbergo, A. (2009). Democracy and foreign education. The American Economic Review, 99(1), pp. 528-543.

Thurston, A. (2013). Mali: The Disintegration of a "Model African Democracy". Stability, 2(1), pp. 1-7.

Wahba, J. (2015). Selection, selection, selection: the impact of return migration. Journal of Population Economics, 28(3), 535-563.

Whitehouse, B. (2012). What went wrong with Mali? London Review of Books, 34, (16), pp. 17-18.

Wing, S. D. (2013). Mali: Politics of a crisis. African Affairs, 112(448), 476-485. first published online May 29, 2013. doi: 10. 1093/afraf/adt037

World Bank. (2015). World Development Indicators'. Washington, DC: World Bank. Retrieved from http://databank. worldbank.org/data/reports.aspx?source=world-development-indicators\#advancedDownloadOptions. Accessed March 2016.

\section{Submit your manuscript to a SpringerOpen ${ }^{\circ}$ journal and benefit from:}

- Convenient online submission

- Rigorous peer review

- Immediate publication on acceptance

- Open access: articles freely available online

- High visibility within the field

- Retaining the copyright to your article

Submit your next manuscript at $\boldsymbol{\nabla}$ springeropen.com 